Check for updates

Cite this: Chem. Sci., 2018, 9, 7078

๑ All publication charges for this article have been paid for by the Royal Society of Chemistry

Received 23rd May 2018 Accepted 12th July 2018

DOI: $10.1039 / c 8 s c 02270 d$

rsc.li/chemical-science

\section{The coordination chemistry of $\mathrm{Cm}^{\mathrm{III}}, \mathrm{Am}^{\mathrm{III}}$, and $\mathrm{Ac} \mathrm{C}^{\mathrm{III}}$ in nitrate solutions: an actinide $\mathrm{L}_{3}$-edge EXAFS study + t:}

\author{
Maryline G. Ferrier, ${ }^{a}$ Benjamin W. Stein, ${ }^{a}$ Sharon E. Bone, ${ }^{a}$ Samantha K. Cary, ${ }^{a}$ \\ Alexander S. Ditter, ${ }^{\text {ab }}$ Stosh A. Kozimor, ID *a Juan S. Lezama Pacheco, ${ }^{c}$ \\ Veronika Mocko ${ }^{a}$ and Gerald T. Seidler ${ }^{b}$
}

Understanding actinide(III) ( $\mathrm{An}^{\prime \prime \prime \prime}=\mathrm{Cm}^{\mathrm{III}}, \mathrm{Am}^{\mathrm{III}}, \mathrm{AC}^{\mathrm{III}}$ ) solution-phase speciation is critical for controlling many actinide processing schemes, ranging from medical applications to reprocessing of spent nuclear fuel. Unfortunately, in comparison to most elements in the periodic table, An ${ }^{\text {III }}$ speciation is often poorly defined in complexing aqueous solutions and in organic media. This neglect - in large part - is a direct result of the radioactive properties of these elements, which make them difficult to handle and acquire. Herein, we surmounted some of the handling challenges associated with these exotic $5 f$-elements and characterized $\mathrm{Cm}^{\prime \prime \prime}, \mathrm{Am}^{\text {III}}$, and $\mathrm{Ac}^{\mathrm{III}}$ using $\mathrm{An}^{\mathrm{III}} \mathrm{L}_{3}$-edge $\mathrm{X}$-ray absorption spectroscopy (XAS) as a function of increasing nitric acid $\left(\mathrm{HNO}_{3}\right)$ concentration. Our results revealed that actinide aquo ions, $\mathrm{An}\left(\mathrm{H}_{2} \mathrm{O}\right)_{x}{ }^{3+}(x=9.6 \pm 0.7$, $8.9 \pm 0.8$, and $10.0 \pm 0.9$ for $\mathrm{Cm}^{\prime \prime \prime}, \mathrm{Am}^{\prime \prime \prime}$, and $\left.\mathrm{Ac}^{\prime \prime \prime \prime}\right)$, were the dominant species in dilute $\mathrm{HNO}_{3}(0.05 \mathrm{M})$. In

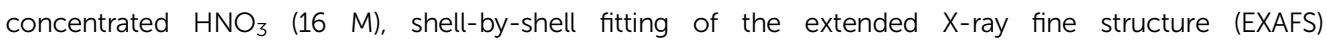
data showed the nitrate complexation increased, such that the average stoichiometries of $\mathrm{Cm}\left(\mathrm{NO}_{3}\right)_{4.1 \pm 0.7}\left(\mathrm{H}_{2} \mathrm{O}\right)_{5.7 \pm 1.3^{(1.1 \pm 0.2)-}}, \mathrm{Am}\left(\mathrm{NO}_{3}\right)_{3.4 \pm 0.7}\left(\mathrm{H}_{2} \mathrm{O}\right)_{5.4 \pm 0.5^{(0.4 \pm 0.1)-}}$, and $\mathrm{Ac}\left(\mathrm{NO}_{3}\right)_{2.3 \pm 1.7}\left(\mathrm{H}_{2} \mathrm{O}\right)_{8.3 \pm 5.2^{(0.7 \pm 0.5)+}}$ were observed. Data obtained at the intermediate $\mathrm{HNO}_{3}$ concentration $(4 \mathrm{M})$ were modeled as a linear combination of the 0.05 and $16 \mathrm{M}$ spectra. For all three metals, the intermediate models showed larger contributions from the $0.05 \mathrm{M} \mathrm{HNO}_{3}$ spectra than from the $16 \mathrm{M} \mathrm{HNO}_{3}$ spectra. Additionally, these efforts enabled the $\mathrm{Cm}-\mathrm{NO}_{3}$ and $\mathrm{Ac}-\mathrm{NO}_{3}$ distances to be measured for the first time. Moreover, the $\mathrm{An}{ }^{\text {III }} \mathrm{L}_{3}$-edge EXAFS results, contribute to the growing body of knowledge associated with $\mathrm{Cm}^{\prime \prime \prime}, \mathrm{Am}^{\prime \prime \prime}$, and $\mathrm{Ac}^{\prime \prime \prime}$ coordination chemistry, in particular toward advancing understanding of $\mathrm{An}^{\text {III }}$ solution phase speciation.

\section{Introduction}

The actinide(III) $\left(\mathrm{An}^{\mathrm{III}}\right)$ cations of $\mathrm{Cm}^{\mathrm{III}}, \mathrm{Am}^{\mathrm{III}}$, and $\mathrm{Ac}^{\mathrm{III}}$ occupy central roles in numerous nuclear technologies important to society. These range from the medical applications in the targeted alpha therapeutic treatment of disease $\left(\mathrm{Ac}^{\mathrm{III}}\right)^{1-3}$ to being critical components in advanced nuclear fuel cycles $\left(\mathrm{Am}^{\mathrm{III}}\right.$ and $\left.\mathrm{Cm}^{\mathrm{III}}\right) .^{4-9}$ Solving technical problems in these areas require detailed understanding of fundamental +3 f-element chemistry. Unfortunately, aside from a limited number of experimental and computational studies, ${ }^{\mathbf{1 0 - 2 1}}$ the chemistry of $\mathrm{Cm}^{\mathrm{III}}, \mathrm{Am}^{\mathrm{III}}$, and $\mathrm{Ac}^{\mathrm{III}}$ is underdeveloped in comparison to the d-block, main

\footnotetext{
${ }^{a}$ Los Alamos National Laboratory, , Los Alamos, New Mexico 87545, USA. E-mail: stosh@lanl.gov

${ }^{b}$ Department of Physics, University of Washington, Seattle, Washington 98195-1560, USA

'Stanford University, Stanford, California 94305, USA

$\dagger$ LA-UR-18-22688.

\$ Electronic supplementary information (ESI) available. See DOI: $10.1039 / \mathrm{c} 8 \mathrm{sc} 02270 \mathrm{~d}$
}

group, and many other $4 \mathrm{f}-$ and 5 f-elements. This discrepancy in large part - is related to the rarity of these elements combined with handling difficulties that accompany the radioactive $\mathrm{Cm}$, Am, and Ac isotopes.

This manuscript documents our latest effort to address needs for advancing fundamental $\mathrm{Cm}^{\mathrm{III}}, \mathrm{Am}^{\mathrm{III}}$, and $\mathrm{Ac}^{\mathrm{III}}$ chemistry. We focused on characterizing the coordination chemistry of these elements in an aqueous environment that contained actinide complexation agents, namely within nitric acid $\left(\mathrm{HNO}_{3}\right)$ solutions. These results are of particular relevance, given the importance of $\mathrm{HNO}_{3}$ matrices in $\mathrm{An}^{\mathrm{III}}$ separation processing. For $\mathrm{Cm}^{\mathrm{III}}$ and $\mathrm{Am}^{\mathrm{III}}, \mathrm{HNO}_{3}$ solutions find widespread application in almost every advanced nuclear fuel processing flow chart., ${ }^{\mathbf{4} 2-24}$ Additionally, $\mathrm{HNO}_{3}$ is widely used in the production of ${ }^{225} \mathrm{Ac}$ for medical purposes (targeted alpha therapy), both in terms of purifying ${ }^{225} \mathrm{Ac}$ from ${ }^{232} \mathrm{Th}$ targets irradiated with high energy protons ${ }^{25-27}$ and when isolating ${ }^{225} \mathrm{Ac}$ from ${ }^{229} \mathrm{Th}$ generators. ${ }^{28-30}$ Towards these ends, we contribute an $\mathrm{An}^{\mathrm{III}} \mathrm{L}_{3}$-edge X-ray absorption spectroscopy (XAS) study focused on characterizing $\mathrm{Cm}^{\mathrm{III}}, \mathrm{Am}^{\mathrm{III}}$, and $\mathrm{Ac}^{\mathrm{III}}$ solutionphase coordination chemistry as a function of increasing $\mathrm{HNO}_{3}$ 
concentration. Our data provided the first $\mathrm{An}^{\mathrm{III}}-\mathrm{NO}_{3}$ bond distance measurements for $\mathrm{Cm}^{\mathrm{III}}$ and $\mathrm{Ac}^{\mathrm{III}}$ of any kind (i.e. solid or solution) and represented the first $\mathrm{Am}^{\mathrm{III}}-\mathrm{NO}_{3}$ measurement made in $\mathrm{HNO}_{3}$ solutions. We observed that at low $\mathrm{HNO}_{3}$ concentrations $(0.05 \mathrm{M}), \mathrm{Cm}^{\mathrm{III}}, \mathrm{Am}^{\mathrm{III}}$, and $\mathrm{Ac}^{\mathrm{III}}$ existed as aquo ions. The propensity of $\mathrm{NO}_{3}{ }^{-}$to complex the $\mathrm{An}^{\mathrm{III}}$ cations increased with increasing $\mathrm{HNO}_{3}$ concentration, such that in $\mathrm{HNO}_{3}(16 \mathrm{M})$ solutions there were 2 to 4 bound $\mathrm{NO}_{3}{ }^{-}$ligands. The results have been presented in the context of the limited number of $\mathrm{HNO}_{3}$ speciation studies reported previously.

\section{Results and discussion}

\section{Sample preparation}

Samples were generated by first preparing chemically pure $\mathrm{Cm}^{\text {III }}, \mathrm{Am}^{\text {III }}$ and $\mathrm{Ac}^{\text {III }}$ stock solutions, as previously described. ${ }^{12,20,31} \mathrm{Next}$, aliquots that contained $\mathrm{Cm}^{\mathrm{III}}(0.5 \mathrm{mg}$ in $0.5 \mathrm{~mL}, 4.0 \mathrm{mM}), \mathrm{Am}^{\mathrm{III}}(0.5 \mathrm{mg}$ in $0.5 \mathrm{~mL}, 4.1 \mathrm{mM})$, and $\mathrm{Ac}^{\mathrm{III}}(28$ $\mu \mathrm{g}$ in $0.3 \mathrm{~mL}, 0.4 \mathrm{mM}$ ) were heated to soft dryness. The resulting residues were dissolved in the desired concentration of nitric acid $\left(\mathrm{HNO}_{3} ; 0.05,4\right.$, or $\left.16 \mathrm{M}\right)$. This process was repeated for a total of three times to ensure that the final $\mathrm{HNO}_{3}$ concentrations were as close to $0.05,4$ and $16 \mathrm{M}$ as possible. Samples were then loaded into XAS holders equipped with three layers of containment to guard against release of radiological material during shipment and data acquisition. Next, the holders were shipped to the Stanford Synchrotron Radiation Lightsource (SSRL) for XAS analysis at the $\mathrm{An}^{\mathrm{III}} \mathrm{L}_{3}$-edge on beam line 11-2.

\section{$\mathrm{An}^{\mathrm{III}} \mathbf{L}_{3}$-edge X-ray absorption near edge spectroscopy (XANES)}

The room temperature $\mathrm{Cm}^{\mathrm{III}}, \mathrm{Am}^{\mathrm{III}}$ and $\mathrm{Ac}^{\mathrm{III}} \mathrm{L}_{3}$-edge XANES spectra obtained from aqueous solutions that contained increasing amounts of nitric acid $\left(\mathrm{HNO}_{3} ; 0.05,4,16 \mathrm{M}\right)$ were background subtracted and normalized (Fig. 1). Each spectrum contained a pronounced absorption peak superimposed on an ionization threshold. From the perspective of the free ion, the edge-feature could be crudely described as originating from electric-dipole allowed transitions from the actinide 2p-orbitals to unoccupied states that contained actinide $6 \mathrm{~d}$-character, i.e. for $\mathrm{Ac}^{\mathrm{III}} 2 \mathrm{p}^{6} \cdots 5 \mathrm{f}^{0} 6 \mathrm{~d}^{0} \rightarrow 2 \mathrm{p}^{5} \cdots 5 \mathrm{f}^{0} 6 \mathrm{~d}^{1} .^{32,33}$ The inflection points and peak maxima were determined graphically where the second derivatives (inflection point) and first derivatives (peak maxima) of the data equaled zero (Table 1). These values were impacted marginally by changes in $\mathrm{HNO}_{3}$ concentration: the inflection points for $\mathrm{Cm}^{\mathrm{III}}$ were centered around $18976 \mathrm{eV}$, for $\mathrm{Am}^{\mathrm{III}}$ near $18514 \mathrm{eV}$, and for $\mathrm{Ac}^{\mathrm{III}}$ close to $15875 \mathrm{eV}$. Based on our previous experience in reproducing actinide $\mathrm{L}_{3}$-edge features, ${ }^{12,21,34-41}$ uncertainties in edge and peak positions were estimated to be on the order of $0.2 \mathrm{eV}$. Hence, for a given element $\left(\mathrm{Cm}^{\mathrm{III}}, \mathrm{Am}^{\mathrm{III}}\right.$, or $\left.\mathrm{Ac}^{\mathrm{III}}\right)$, the $0.05,4$, and $16 \mathrm{M}$ absorption edges and peak positions were nearly equivalent.

Although the absorption peak position showed essentially no dependence on the $\mathrm{HNO}_{3}$ concentration, changing the $\mathrm{HNO}_{3}$ concentration from $0.05 \mathrm{M}$ to $16 \mathrm{M}$ had a marked impact on the energy of the post-edge feature approximately 30 to $40 \mathrm{eV}$ above the inflection point (Fig. 1). This peak marks the first extended

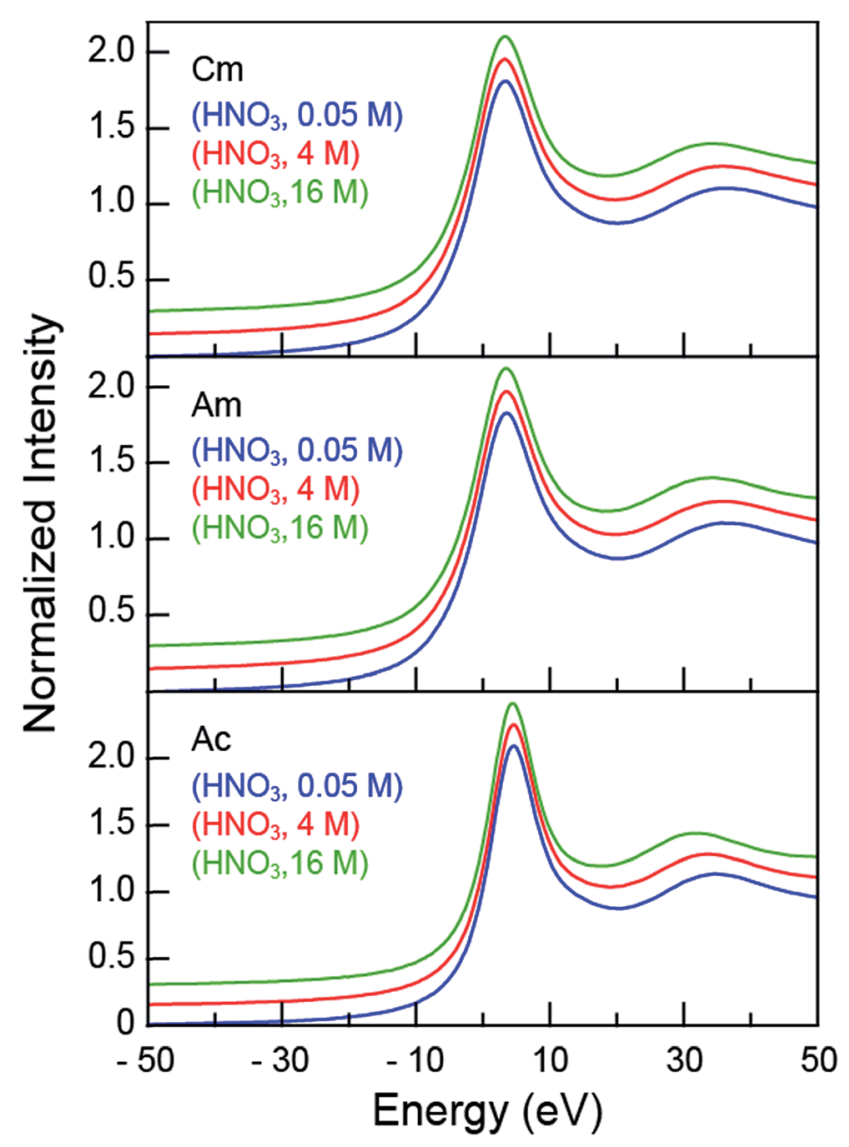

Fig. 1 The background subtracted and normalized room temperature solution-phase $\mathrm{An}^{\prime \prime \prime} \mathrm{L}_{3}$-edge XANES spectra of $\mathrm{An}^{\prime \prime \prime}\left(\mathrm{An}=\mathrm{Cm}^{\prime \prime \prime}\right.$, top; Am ${ }^{\prime \prime \prime}$, middle; $A C^{\prime \prime \prime}$, bottom) cations dissolved in $\mathrm{HNO}_{3}(0.05 \mathrm{M}$, blue trace; $4 \mathrm{M}$, red trace; and $16 \mathrm{M}$, green trace). Spectra are displayed with a slight $y$-offset for clarity.

X-ray absorption fine structure (EXAFS) oscillation. Increasing the $\mathrm{HNO}_{3}$ concentration systematically lowered the energy for the oscillation maximum (Table 1). For $\mathrm{Cm}^{\mathrm{III}}$, moving from $0.05 \mathrm{M}$ to $4 \mathrm{M} \mathrm{HNO}_{3}$ caused a $0.6 \mathrm{eV}$ oscillation maximum decrease. Similarly, moving from $4 \mathrm{M}$ to $16 \mathrm{M} \mathrm{HNO}_{3}$ caused a $-2.1 \mathrm{eV}$ energy shift. Similar trends were observed for $\mathrm{Am}^{\mathrm{III}}$ and $\mathrm{Ac}^{\mathrm{III}}$, albeit the $3.5\left(\mathrm{Am}^{\mathrm{III}}\right)$ and $3.1\left(\mathrm{Ac}^{\mathrm{III}}\right)$ energy shifts were larger. Dependence of the post-edge line-shape on the $\mathrm{HNO}_{3}$ concentration foreshadowed structural changes that accompanied coordination of $\mathrm{An}^{\mathrm{III}}$ cations by $\mathrm{NO}_{3}{ }^{-}$ligands, which were revealed when the EXAFS spectra were rigorously analyzed.

\section{$\mathrm{An}^{\mathrm{III}} \mathbf{L}_{3}$-edge extended X-ray absorption fine structure (EXAFS) spectroscopy}

Speciation metrics (i.e. coordination numbers and bond distances) for solution-phase samples were extracted from the $k^{3} \chi(k)$ solution-phase measurements (Fig. 2). For $\mathrm{Cm}^{\mathrm{III}}$ and $\mathrm{Am}^{\mathrm{III}}$ - present in relatively high concentrations $(0.5 \mathrm{mg}$ in $0.5 \mathrm{~mL}$ per sample) - high quality data were obtained from 2.7 to $11 \AA^{-1}$ (in $k$-space). This energy range provided shell-by-shell resolution in the $\mathrm{Cm}^{\mathrm{III}}$ and $\mathrm{Am}^{\mathrm{III}}$ measurements to be approximately $0.19 \AA$ (resolution $=\pi / 2 \Delta k$; in $R$-space). The $\mathrm{Cm}^{\mathrm{III}}$ and $\mathrm{Am}^{\mathrm{III}} \mathrm{L}_{3}$-edge $k^{3} \chi(k)$ spectra were quite similar and changed 
Table 1 Inflection points and peak positions (eV) of the room-temperature $\mathrm{Cm}^{\text {I"I }}$, Am"', and Ac'"I $\mathrm{L}_{3}$-edge solution-phase XANES spectra of An ${ }^{\prime \prime \prime}$ dissolved in $\mathrm{HNO}_{3}(0.05,4$ and $16 \mathrm{M})$. The $\mathrm{Cm}^{\text {III }}$ and $\mathrm{Am}^{\text {III }}$ spectra were calibrated to the peak maximum of a $\mathrm{Zr}$ foil (18 $\left.013.3 \mathrm{eV}\right)$ while the Ac ${ }^{\prime \prime \prime}$ spectra were calibrated to the first inflection point of a RbCl pellet (15 $203.8 \mathrm{eV})$

\begin{tabular}{|c|c|c|c|}
\hline & Inflection point $(\mathrm{eV})$ & Peak position $(\mathrm{eV})$ & $2^{\text {nd }}$ peak position $(\mathrm{eV})$ \\
\hline $\mathrm{Cm}$ aquo $\left(1 \mathrm{M} \mathrm{HClO}_{4}\right),{ }^{47 a}$ & 18973.0 & - & - \\
\hline $\mathrm{Cm}\left(\mathrm{HNO}_{3}, 0.05 \mathrm{M}\right)$ & 18976.4 & 18980.3 & 19013.5 \\
\hline $\mathrm{Cm}\left(\mathrm{HNO}_{3}, 16 \mathrm{M}\right)$ & 18976.3 & 18980.2 & 19011.4 \\
\hline $\operatorname{Am}\left(0.11 \mathrm{M} \mathrm{HO}_{3} \mathrm{SCF}_{3}\right),{ }^{21}$ & 18514.3 & 18517.9 & \\
\hline $\mathrm{Am}\left(\mathrm{HNO}_{3}, 0.05 \mathrm{M}\right)$ & 18514.0 & 18517.5 & 18550.6 \\
\hline Ac $\left(0.11 \mathrm{M} \mathrm{HO}_{3} \mathrm{SCF}_{3}\right){ }^{12}$ & 15874.3 & 15876.9 & \\
\hline $\mathrm{Ac}\left(\mathrm{HNO}_{3}, 0.05 \mathrm{M}\right)$ & 15874.7 & 15877.6 & 15908.1 \\
\hline $\mathrm{Ac}\left(\mathrm{HNO}_{3}, 4 \mathrm{M}\right)$ & 15874.6 & 15877.5 & 15906.7 \\
\hline $\mathrm{Ac}\left(\mathrm{HNO}_{3}, 16 \mathrm{M}\right)$ & 15874.6 & 15877.5 & 15905.0 \\
\hline
\end{tabular}

uniformly with increasing $\mathrm{HNO}_{3}$ concentration (Fig. 2). The first three oscillations were nearly superimposable despite the changes in $\mathrm{HNO}_{3}$ concentration. Upon reaching the fourth and fifth oscillations, some dependence on the $\mathrm{HNO}_{3}$ concentration became apparent. For example, moving from $0.05 \mathrm{M}$ to $4 \mathrm{M}$ $\mathrm{HNO}_{3}$ caused a subtle shoulder to emerge in the fifth oscillation (ca. $9 \AA^{-1}$ ). Changing to concentrated $\mathrm{HNO}_{3}(16 \mathrm{M})$ increased the magnitude of this shoulder and caused a second shoulder to emerge on the low energy side of the fourth oscillation ( $c a$. $7.5 \AA^{-1}$ ). These line shape changes suggested that some of the scattering pathways were moving out of phase.
In general, the Ac ${ }^{\mathrm{III}}$ spectra were similar to those of $\mathrm{Cm}^{\mathrm{III}}$ and Am ${ }^{\text {III }}$. For example, increased $\mathrm{HNO}_{3}$ concentrations had little impact on the first three oscillations and showed evidence of out-of-phase scattering pathways for the fourth and fifth oscillations. The $\mathrm{Ac}^{\mathrm{III}} \mathrm{L}_{3}$-edge data differed in two notable ways. First, the signal-to-noise ratio was smaller, on account of the smaller quantity of $\mathrm{Ac}^{\mathrm{III}}(28 \mu \mathrm{g})$. This restricted the energy range over which high quality data were available; from 2.7 to 9.5 in $k$ space (resolution $=0.23 \AA$ in $R$-space). Second, the EXAFS oscillation frequency increased in comparison to those of $\mathrm{Cm}^{\mathrm{III}}$ and $\mathrm{Am}^{\mathrm{III}}$. This frequency increase was somewhat expected. For

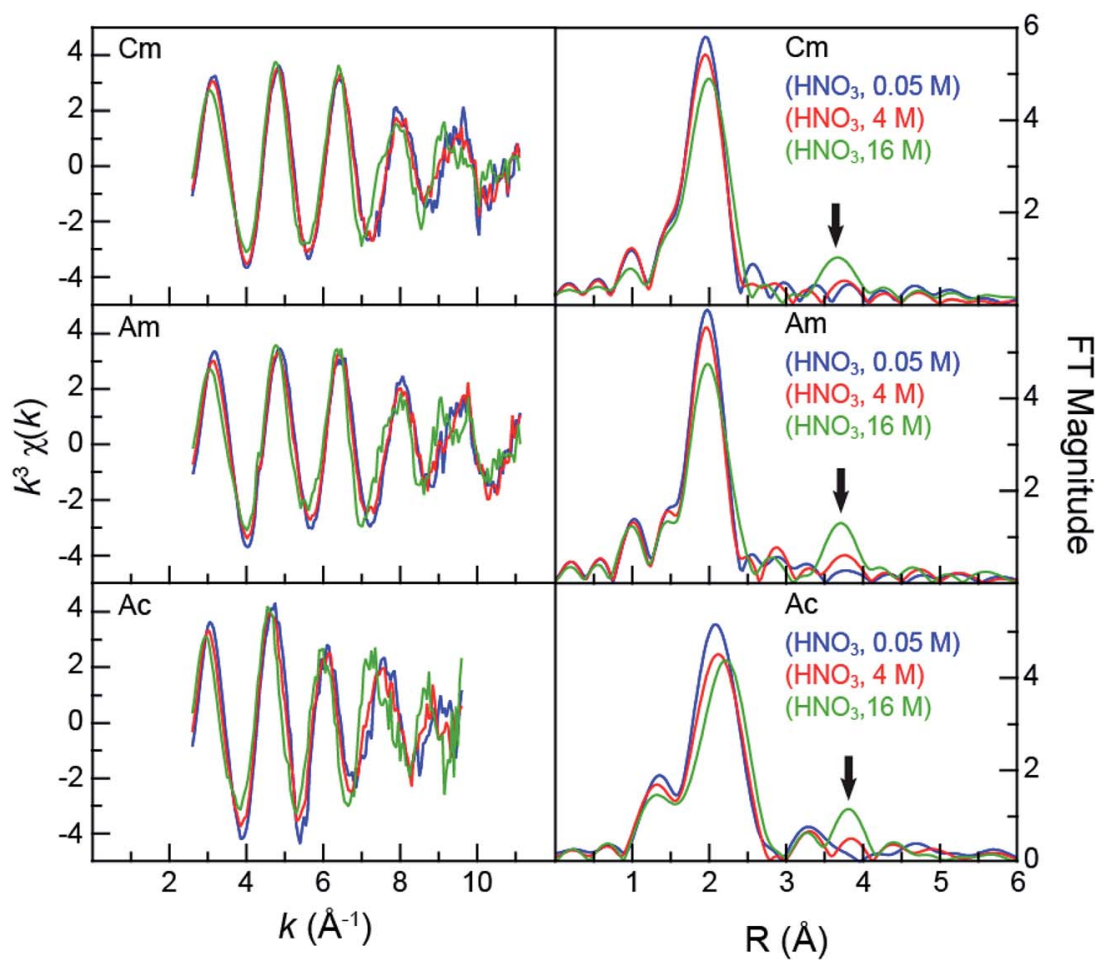

Fig. 2 Left - the room temperature $A n^{\prime \prime \prime} L_{3}$-edge EXAFS function $k^{3} \chi(k)$ from $A n^{\prime \prime \prime}\left(A n=C^{\prime \prime \prime \prime}\right.$, top; Am"', middle; Ac ${ }^{\prime \prime \prime}$, bottom) cations dissolved in $\mathrm{HNO}_{3}\left(0.05 \mathrm{M}\right.$, blue trace; $4 \mathrm{M}$, red trace; and $16 \mathrm{M}$, green trace). Right - the Fourier Transform of $k^{3}$-EXAFS spectra. The black arrow emphasizes the growing nitrate contribution to the spectra. 
example, the frequency in $k$-space (left, Fig. 2) is inversely related to the interatomic distance. Higher frequencies result from longer bonds. As shown in Fig. 2, the large $\mathrm{Ac}^{\mathrm{III}}$ ionic radius $^{42}$ should provide longer bond distances (higher oscillation frequencies) than those for $\mathrm{Cm}^{\mathrm{III}}$ and $\mathrm{Am}^{\mathrm{III}}$, as long as the analytes have similar chemical compositions. Given the observed change in frequency upon moving from $\mathrm{Cm}^{\mathrm{III}}$ and $\mathrm{Am}^{\mathrm{III}}$ to $\mathrm{Ac}^{\mathrm{III}}$ and the similar interference pattern, these data suggested - superficially - that the $\mathrm{Ac}{ }^{\mathrm{III}}$ speciation was similar to that of $\mathrm{Am}^{\mathrm{III}}$ and $\mathrm{Cm}^{\mathrm{III}}$.

Closer examination of the $\mathrm{Cm}^{\mathrm{III}}, \mathrm{Am}^{\mathrm{III}}$, and $\mathrm{Ac}^{\mathrm{III}} \mathrm{L}_{3}$-edge EXAFS spectra supported the proposition that chemical speciation was similar for these three compounds, revealing only subtle differences in $\mathrm{Cm}^{\mathrm{III}}$, $\mathrm{Am}^{\mathrm{III}}$, and $\mathrm{Ac}^{\mathrm{III}}$ coordination environments. The experimental data were analyzed using wellestablished shell-by-shell curve fitting techniques. ${ }^{43}$ Interpretations of the data were guided by identifying scattering pathways using FEFF8 (ref. 44 and 45) and DFT geometry optimized $\mathrm{An}^{\mathrm{III}}$ structures that contained a combination of water molecules and bidentate nitrate ligands, $\mathrm{An}\left(\mathrm{H}_{2} \mathrm{O}\right)_{9-2 x}\left(\mathrm{NO}_{3}\right)_{x}{ }^{3-x}\left(\mathrm{An}=\mathrm{Cm}^{\mathrm{III}}\right.$, $\left.\mathrm{Am}^{\mathrm{III}}, \mathrm{Ac}^{\mathrm{III}} ; x=0,1,2,3\right)$. The coordination numbers (CN), bond lengths $(R)$, Debye-Waller factors $\left(\sigma^{2}\right)$, and energy shifts $\left(E_{0}\right)$ were allowed to converge to reasonable values. The amplitude reduction factor was set to 0.9 . The fitting results have been summarized and compared with other relevant EXAFS studies in Table 2. ${ }^{12,21,46,47}$ For the sake of discussion, we begin by reporting on spectra collected in dilute $\mathrm{HNO}_{3}(0.05 \mathrm{M})$, then move to concentrated $\mathrm{HNO}_{3}(16 \mathrm{M})$, and conclude at the intermediate $\mathrm{HNO}_{3}$ concentration $(4 \mathrm{M})$.

As shown in Fig. 2, all spectra collected from dilute $\mathrm{HNO}_{3}$ $(0.05 \mathrm{M})$ solutions were best described by a single frequency whose amplitude in $k$-space (left, Fig. 2) dampened with increased energy. Best fits for the data (top, Fig. 3; Table 2) those with the smallest residuals and lowest reduced chisquared values - confirmed this superficial interpretation. The histogram of frequencies shown in the Fourier transform spectra (right, Fig. 2; top, Fig. 3) contained a single peak near $R$ $=2 \AA$. As the frequency resolution ranged from 0.19 to $0.23 \AA$ for $\mathrm{Cm}^{\text {III, }}, \mathrm{Am}^{\text {III }}$, and $\mathrm{Ac}^{\mathrm{III}}$, we refrained from attempting to resolve multiple $\mathrm{M}-\mathrm{O}_{\mathrm{H}_{2} \mathrm{O}}$ scattering pathways within this first water shell. Furthermore, the data quality was not sufficient for observing $\mathrm{H}_{2} \mathrm{O}$ molecules at longer distances, i.e. in the second and third hydration shells. Fitting the data with a single $\mathrm{H}_{2} \mathrm{O}$ shell revealed approximately nine water molecules for $\mathrm{Cm}^{\mathrm{III}}(9.6 \pm 0.7)$ and $\mathrm{Am}^{\mathrm{III}}(8.9 \pm 0.8)$ with equivalent $\mathrm{M}-\mathrm{O}_{\mathrm{H}_{2} \mathrm{O}}$ distances of 2.47(1) A. These results agreed well with the literature values for $\mathrm{Cm}^{\text {III }}$ and $\mathrm{Am}^{\text {III }}$ aquo ions. The single crystal structure of the $\mathrm{Cm}^{\mathrm{III}}$ aquo ion showed nine $\mathrm{H}_{2} \mathrm{O}$ ligands with an average $\mathrm{Cm}-$ $\mathrm{O}_{\mathrm{H}_{2} \mathrm{O}}$ distance of 2.51(8) $\AA^{48} .^{48}$ Previous EXAFS measurements obtained from the $\mathrm{Cm}^{\mathrm{III}}$ aquo ion in dilute $\mathrm{HCl}(0.25 \mathrm{M})^{46}$ and dilute $\mathrm{HClO}_{4}(1 \mathrm{M})^{47}$ showed $10.2 \pm 0.3$ oxygen atoms at $2.450(2) \AA$ and $7.0 \pm 0.4$ oxygen atoms at 2.469(7) $\AA$, respectively. Similarly, recent EXAFS studies characterized the $\mathrm{Am}^{\mathrm{III}}$ aquo ion as having $9.5 \pm 0.9$ oxygen atoms at $2.48(1) \AA\left(\mathrm{HO}_{3} \mathrm{SCF}_{3} ; 0.11 \mathrm{M}\right)^{21}$ and $10.3 \pm 0.3$ oxygen atoms at $2.480(2) \AA(\mathrm{HCl} ; 0.25 \mathrm{M}) .{ }^{46} \mathrm{~A}$ single crystal structure for the $\mathrm{Am}^{\mathrm{III}}$ aquo ion has also been reported, showing nine $\mathrm{H}_{2} \mathrm{O}$ ligands with a $2.52(8) \AA$ average $\mathrm{Am}-\mathrm{O}_{\mathrm{H}_{2} \mathrm{O}}$ distance. ${ }^{48}$

For the larger $\mathrm{Ac}^{\mathrm{III}}$ cation, a longer $\mathrm{Ac}-\mathrm{O}_{\mathrm{H}_{2} \mathrm{O}}$ distance of 2.63(2) $\AA$ was observed. In comparison to the $\mathrm{Cm}^{\mathrm{III}}$ and $\mathrm{Am}^{\mathrm{III}}$ aquo ions described above, the larger $\mathrm{Ac}-\mathrm{O}_{\mathrm{H}_{2} \mathrm{O}}$ bond distance was statistically relevant. The $\mathrm{Ac}{ }^{\mathrm{III}}$ coordination number also seemed larger than those from $\mathrm{Cm}^{\mathrm{III}}$ and $\mathrm{Am}^{\mathrm{III}}$ with $10.0 \pm 0.9$ inner sphere $\mathrm{H}_{2} \mathrm{O}$ ligands. However, these values were equivalent when the measurement uncertainties were considered. The Ac- $\mathrm{O}_{\mathrm{H}_{2} \mathrm{O}}$ bond distance and $\mathrm{H}_{2} \mathrm{O}$ coordination numbers were consistent with the only other data obtained on an $\mathrm{Ac}^{\mathrm{III}}$ aquo ion, ${ }^{12}$ despite differences in the solution matrices; $\mathrm{HNO}_{3}(0.05$ M) vs. $\mathrm{HO}_{3} \mathrm{SCF}_{3}(0.11 \mathrm{M})$. This previous analysis showed $10.9 \pm$ 0.5 oxygen atoms at 2.63(1) $\AA$. Additional confidence in these Ac- $\mathrm{O}_{\mathrm{H}_{2} \mathrm{O}}$ distances was provided by comparison with previous $\mathrm{Ac}^{\mathrm{III}} \mathrm{L}_{3}$-edge EXAFS measurements made in $\mathrm{HCl}(11.7 \mathrm{M})$ solutions, which gave a 2.59(3) $\mathrm{A}$ Ac- $\mathrm{O}_{\mathrm{H}_{2} \mathrm{O}}$ distance. ${ }^{21}$ Overall, all of our $\mathrm{An}-\mathrm{O}_{\mathrm{H}_{2} \mathrm{O}}\left(\mathrm{An}=\mathrm{Cm}^{\mathrm{III}}, \mathrm{Am}^{\mathrm{III}}, \mathrm{Ac}^{\mathrm{III}}\right)$ distances were in agreement with the Shannon ionic radii. ${ }^{42}$ For example, subtracting the six coordinate ionic radii from the experimental $\mathrm{M}-\mathrm{O}_{\mathrm{H}_{2} \mathrm{O}}$ distances gave 1.50, 1.50, and $1.51 \AA$ for $\mathrm{Cm}^{\mathrm{III}}, \mathrm{Am}^{\mathrm{III}}$, and $\mathrm{Ac}^{\mathrm{III}}$, respectively. These values were bracketed by the calculated (1.67 A) and crystallographically measured $(1.38 \AA) \mathrm{H}_{2} \mathrm{O}$ ionic radii. ${ }^{49}$ In all of the $\mathrm{An}^{\mathrm{III}}$ aquo spectra $\left(\mathrm{HNO}_{3}, 0.05 \mathrm{M}\right.$ for $\mathrm{Cm}^{\mathrm{III}}, \mathrm{Am}^{\mathrm{III}}$, and $\mathrm{Ac}^{\mathrm{III}} ; \mathrm{HO}_{3} \mathrm{SCF}_{3}, 0.11 \mathrm{M}$ for $\mathrm{Am}^{\mathrm{III}}$ and $\left.\mathrm{Ac} c^{\mathrm{III}}\right)$, there was no evidence of $\mathrm{An}^{\mathrm{III}}$ aquo ion dimerization. No $\mathrm{An}^{\mathrm{III}} \cdots \mathrm{An}^{\mathrm{III}}$ scattering pathways were detected nor was there evidence for short $\mathrm{An}^{\mathrm{III}}-\mathrm{OH}$ interactions, which would result from hydrolysis. Hence, these data were consistent with previous EXAFS studies on $\mathrm{An}^{\mathrm{III}}$ and $\mathrm{Ln}^{\mathrm{III}}$ aquo ions, ${ }^{12,50-54}$ suggesting that $\mathrm{Cm}^{\mathrm{III}}, \mathrm{Am}^{\mathrm{III}}$, and $\mathrm{Ac}{ }^{\mathrm{III}}$ aquo ions existed primarily as discrete $\mathrm{An}^{\mathrm{III}}\left(\mathrm{H}_{2} \mathrm{O}\right)_{x}{ }^{3+}$ species. However, EXAFS spectroscopy is relatively insensitive to dilute impurities, and dimeric species present at less than $10 \%$ of the total sample would be difficult to detect. ${ }^{43}$

Consistent with the $\mathrm{Ac}^{\mathrm{III}}$ aquo $\mathrm{L}_{3}$-edge EXAFS spectra reported previously in dilute $\mathrm{HO}_{3} \mathrm{SCF}_{3}$, the data reported here contained a feature near $3.2 \AA$ in the Fourier transform. To date, we have been unable to identify physically realistic models to explain these high-frequency oscillations. Given the instability of these features in various $k$ ranges $\left(7,8,9,10 \AA^{-1}\right)$, at this time we believe their origin is not related to the $\mathrm{Ac}^{\mathrm{III}}$ coordination chemistry and likely results from systematic artifacts related to the data quality. While not conclusive, this proposition was supported by the absence of this mysterious peak in the higher quality $\mathrm{Cm}^{\mathrm{III}}$ and $\mathrm{Am}^{\mathrm{III}}$ spectra, as long as one assumes analogous coordination chemistry exists for all three cations.

Comparison between 0.05 and $16 \mathrm{M} \mathrm{HNO}_{3}$ offered the highest probability to identify differences in $\mathrm{An}^{\mathrm{III}}$ speciation. Our approach to modeling these EXAFS data was consistent with previous models used to explain spectra from $\mathrm{Ln}^{\mathrm{III}}$ and $\mathrm{An}^{\mathrm{III}}$ cations dissolved in $\mathrm{HNO}_{3}\left(6.8 \mathrm{M},{ }^{55} 13 \mathrm{M}\right.$ ) (Scheme 1; bottom, Fig. 3). For $\mathrm{Cm}^{\mathrm{III}}$ and $\mathrm{Am}^{\mathrm{III}}$, there were two short oxygen scattering pathways. The shorter path was assigned to metal

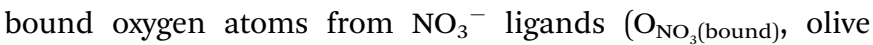
trace); meanwhile the other was attributed to a shell of oxygen atoms from the $\mathrm{H}_{2} \mathrm{O}$ ligands $\left(\mathrm{O}_{\mathrm{H}_{2} \mathrm{O}}\right.$, purple trace, Fig. 3; Scheme 1). However, because these designations resulted from 


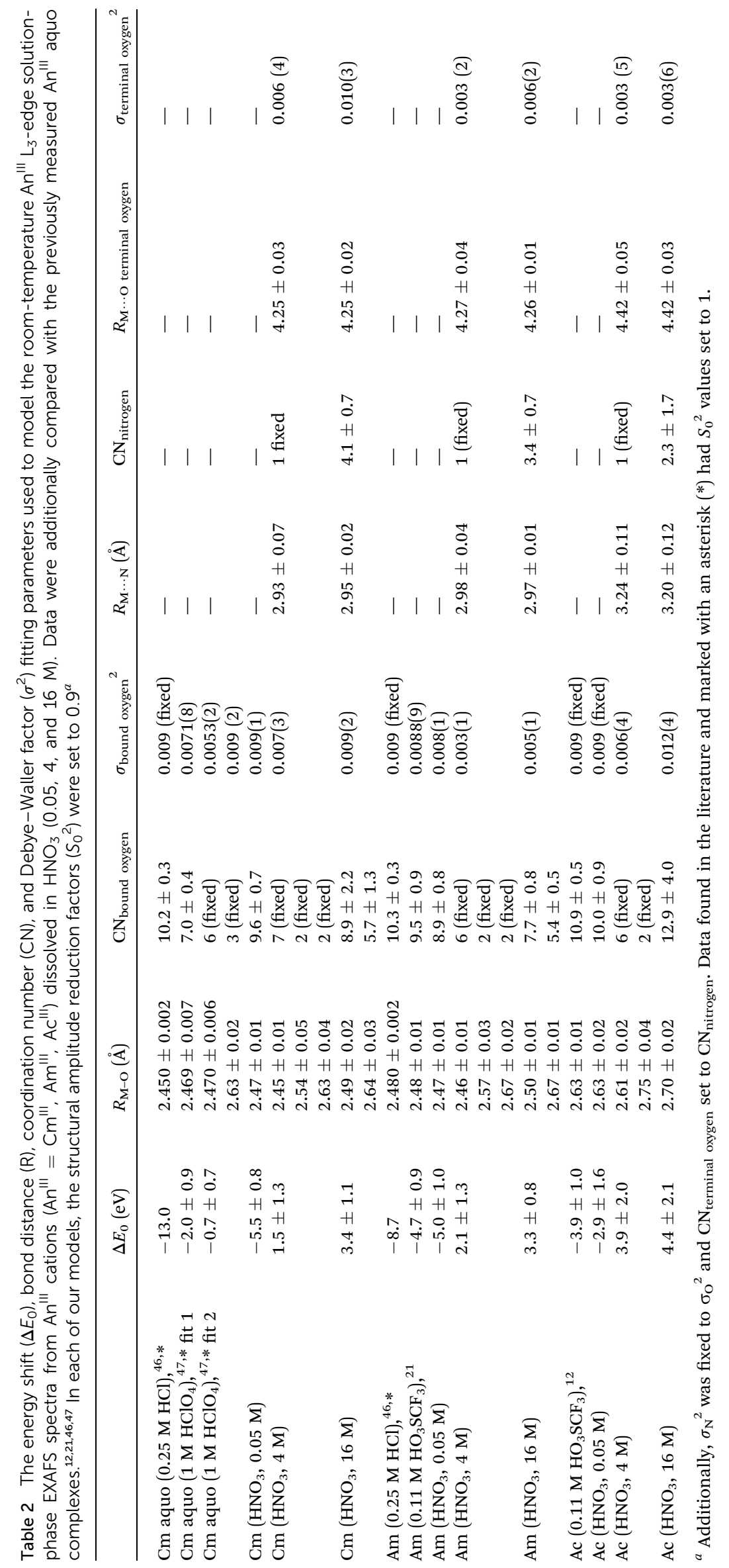




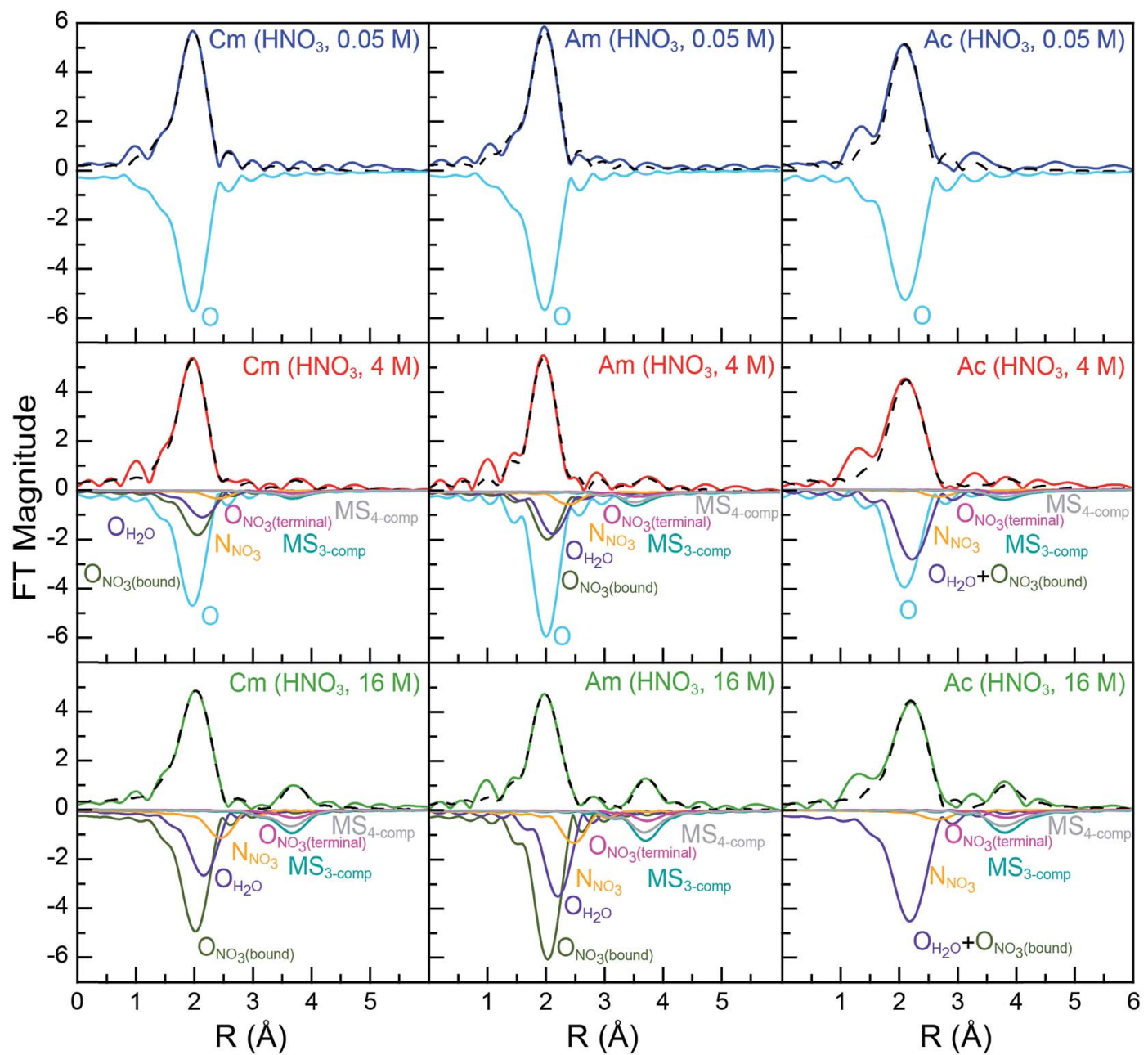

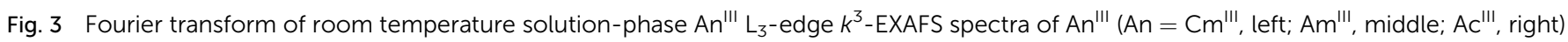
cations dissolved in $\mathrm{HNO}_{3}(0.05 \mathrm{M}$, top, blue trace; $4 \mathrm{M}$, middle, red trace; $16 \mathrm{M}$, bottom, green trace). Fits to the data are shown as dashed black traces and scattering pathway contributions to the fit have been plotted inversely. The dilute $\mathrm{HNO}_{3}$ system $(0.05 \mathrm{M})$ was modeled with a single $\mathrm{H}_{2} \mathrm{O}$ scattering pathway (cyan trace). The concentrated $\mathrm{HNO}_{3}$ system (16 M) was modeled with scattering pathways from $\mathrm{O}_{\mathrm{H}_{2} \mathrm{O}}$ (purple trace),

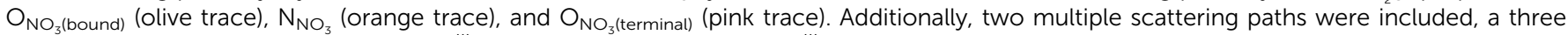

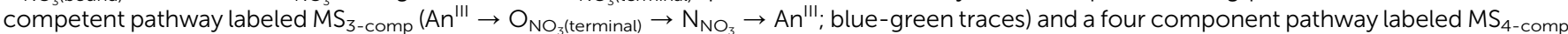

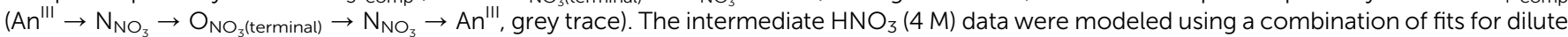
$\mathrm{HNO}_{3}\left(0.05 \mathrm{M}\right.$, cyan scattering pathway) and concentrated $\mathrm{HNO}_{3}$ (16 M; purple, olive, pink, orange, blue-green, and grey scattering pathways) spectra.

calculations on static actinide nitrate molecules, we do not have high confidence in the rigidity of these assignments. For example, in solution, $\mathrm{NO}_{3}{ }^{-}$and $\mathrm{H}_{2} \mathrm{O}$ ligand exchange could

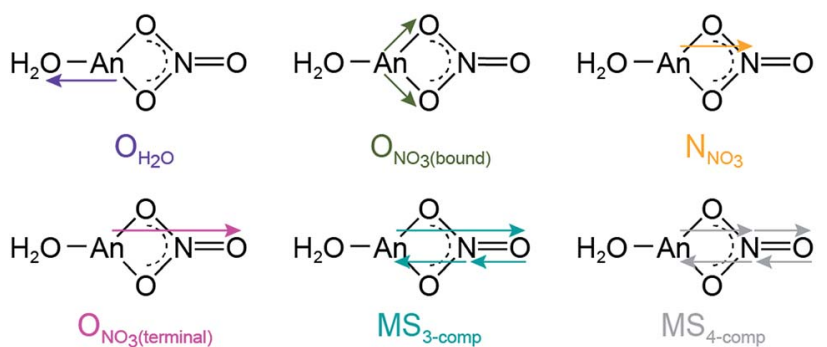

Scheme 1 Scattering pathways deployed in fitting An $\mathrm{L}_{3}$-edge EXAFS data from $\mathrm{An}^{\text {III }}$ cations dissolved in $16 \mathrm{M} \mathrm{HNO}_{3}$ likely occur. For $\mathrm{Ac}^{\mathrm{III}}$, the data were not sufficient to resolve the two $\mathrm{O}_{\mathrm{H}_{2} \mathrm{O}}$ and $\mathrm{O}_{\mathrm{NO}_{3} \text { (bound) }}$ scattering pathways. Hence, in the $\mathrm{Ac}^{\mathrm{III}}$

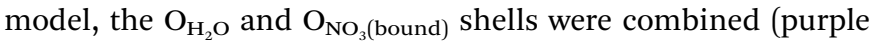
trace, bottom right, Fig. 3).

Consistent with $\mathrm{An}^{\mathrm{III}}-\mathrm{NO}_{3}{ }^{-}$binding was the presence of four higher frequency scattering pathways, characteristic of innersphere $\mathrm{NO}_{3}{ }^{-}$ligands. ${ }^{55}$ There was a pathway at intermediate distances associated with the central nitrogen of the $\mathrm{NO}_{3}{ }^{-}$anion, referred to as $\mathrm{N}_{\mathrm{NO}_{3}}$ (orange trace, Fig. $3 ; c a . R=2.5 \AA$ ). This shell was followed by the $\mathrm{NO}_{3}{ }^{-}$terminal oxygen $\left(\mathrm{O}_{\mathrm{NO}_{3} \text { (terminal); pink }}\right.$ trace, $c a . R=3 \AA$ ). Subsequently, between $c a .3<R<4.5 \AA$ there were two linear multiple scattering pathways. There was the three component $\mathrm{An}^{\mathrm{III}} \rightarrow \mathrm{O}_{\mathrm{NO}_{3} \text { (terminal) }} \rightarrow \mathrm{N}_{\mathrm{NO}_{3}} \rightarrow \mathrm{An}^{\mathrm{III}}\left(\mathrm{MS}_{3}\right.$-comp; blue-green trace) pathway and the four component $\mathrm{An}^{\mathrm{III}} \rightarrow \mathrm{N}_{\mathrm{NO}_{3}}$ $\rightarrow \mathrm{O}_{\mathrm{NO}_{3} \text { (terminal) }} \rightarrow \mathrm{N}_{\mathrm{NO}_{3}} \rightarrow \mathrm{An}^{\mathrm{III}}$ ( $\mathrm{MS}_{4-\text { comp }}$; grey trace) pathway 
(Scheme 1). Our attempts to model the data with bent multiple scattering pathways (i.e. $\mathrm{An}^{\mathrm{III}} \rightarrow \mathrm{O}_{\mathrm{NO}_{3} \text { (bound) }} \rightarrow \mathrm{N}_{\mathrm{NO}_{3}} \rightarrow \mathrm{An}^{\mathrm{III}}$ ) or as dimers and oligomers (with An $\cdots$ An scattering paths) were unsuccessful. Best fits for the data contained $\eta^{2}-\mathrm{NO}_{3}{ }^{-}$(bidentate) ligands and were modeled using the following constraints. The

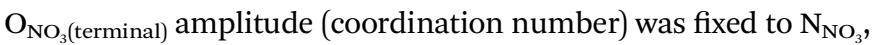
which in turn was allowed to converge. In addition, the $\mathrm{N}_{\mathrm{NO}_{3}}$ and $\mathrm{O}_{\mathrm{NO}_{3} \text { (bound) }}$ Debye-Waller factors $\left(\sigma^{2}\right)$ were fixed to that associated with $\mathrm{O}_{\mathrm{H}_{2} \mathrm{O}}$, as all three scattering pathways had similar frequencies and because these three scattering pathways combined to form a single peak in the Fourier transform. This constraint additionally minimized the number of free fitting parameters.

For $\mathrm{Cm}^{\mathrm{III}}$, refinement of the model to experimental data showed $8.9 \pm 2.2 \mathrm{O}_{\mathrm{NO}_{3} \text { (bound) }}$ atoms at 2.49(2) $\AA$. There were also $5.7 \pm 1.3 \mathrm{O}_{\mathrm{H}_{2} \mathrm{O}}$ at 2.64(3) $\AA$ and $4.1 \pm 0.7 \mathrm{~N}_{\mathrm{NO}_{3}}$ atoms at 2.95(2) $\mathrm{A}$.

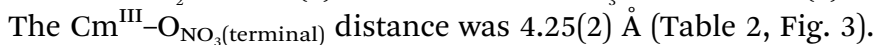
To determine the number of $\mathrm{NO}_{3}{ }^{-}$ligands, two options existed involving either the $\mathrm{N}_{\mathrm{NO}_{3}}$ coordination number or the

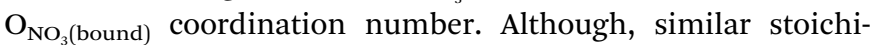
ometries were obtained for both scenarios, reported here is

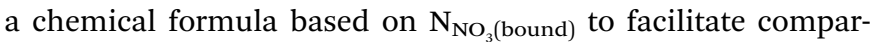
ison with the $\mathrm{Ac}^{\mathrm{III}}$ data below. Overall, these data indicated that the average $\mathrm{Cm}^{\mathrm{III}}$ species present in concentrated $\mathrm{HNO}_{3}(16 \mathrm{M})$ had a stoichiometry of $\mathrm{Cm}\left(\mathrm{NO}_{3}\right)_{4.1 \pm 0.7}\left(\mathrm{H}_{2} \mathrm{O}\right)_{5.7 \pm 1.3}{ }^{(1.1 \pm 0.2)-}$ with an overall coordination number of $13.9 \pm 1.9$. Stoichiometric self-consistency associated with the coordination number ratio for $\mathrm{N}_{\mathrm{NO}_{3}}, \mathrm{O}_{\mathrm{NO}_{3} \text { (bound) }}, \mathrm{O}_{\mathrm{NO}_{3} \text { (terminal) }}(2: 1: 1)$ - as well as the magnitude of the multiple scattering pathways - provided additional confidence in our model.

The $\mathrm{Am}^{\mathrm{III}}$ data in $16 \mathrm{M} \mathrm{HNO}_{3}$ resembled that from $\mathrm{Cm}^{\mathrm{III}}$ (Table 2), albeit with slightly smaller uncertainties. For instance, this analysis showed that the average coordination numbers for all of the $\mathrm{Am}^{\mathrm{III}}$ species present in concentrated $\mathrm{HNO}_{3}$ had $7.7 \pm 0.8 \mathrm{O}_{\mathrm{NO}_{3} \text { (bound) }}$ atoms at 2.50(1) $\AA$, $5.4 \pm 0.5$ $\mathrm{O}_{\mathrm{H}_{2} \mathrm{O}}$ atoms at 2.67(1) $\AA, 3.4 \pm 0.7 \mathrm{~N}_{\mathrm{NO}_{3}}$ atoms at 2.97(1) $\AA$, and

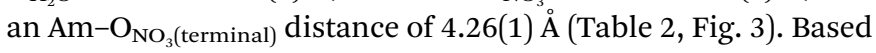
on the $\mathrm{N}_{\mathrm{NO}_{3}}$ and $\mathrm{O}_{\mathrm{H}_{2} \mathrm{O}}$ values, the analysis suggested an average stoichiometry of $\mathrm{Am}\left(\mathrm{NO}_{3}\right)_{3.4 \pm 0.7}\left(\mathrm{H}_{2} \mathrm{O}\right)_{5.4 \pm 0.5}{ }^{(0.4 \pm 0.1)-}$ (mean

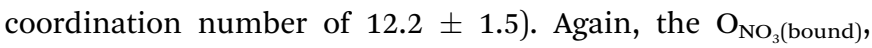

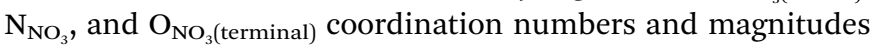
from the multiple scattering pathways were all self-consistent with this average stoichiometry.

Moving to the larger $\mathrm{Ac}^{\mathrm{III}}$ ion had little effect on the overall coordination number, showing $12.9 \pm 4$ inner-sphere oxygen atoms. The average $\mathrm{Ac}\left(\mathrm{NO}_{3}\right)_{2.3 \pm 1.7}\left(\mathrm{H}_{2} \mathrm{O}\right)_{8.3 \pm 5.2}{ }^{(0.7 \pm 0.5)+}$ solution phase stoichiometry was (essentially) equivalent to that from $\mathrm{Cm}^{\mathrm{III}}$ and $\mathrm{Am}^{\mathrm{III}}$; however, the uncertainties associated with the $\mathrm{Ac}^{\mathrm{III}} \mathrm{L}_{3}$-edge measurements were larger. The presence of $2.3 \pm$ $1.7 \mathrm{~N}_{\mathrm{NO}_{3}}$ atoms at 3.20(12) $\AA$ and $\mathrm{Ac}^{\mathrm{III}}-\mathrm{O}_{\mathrm{NO}_{3} \text { (terminal) }}$ atoms at 4.42(3) Å confirmed the presence of inner-sphere $\mathrm{NO}_{3}{ }^{-}$ligands in $\mathrm{HNO}_{3}$ (16 M; Table 2, Fig. 3). The largest differences between the $\mathrm{Cm}^{\mathrm{III}}, \mathrm{Am}^{\mathrm{III}}$, and $\mathrm{Ac}^{\mathrm{III}} \mathrm{L}_{3}$-edge EXAFS data were associated with the $\mathrm{Ac}^{\mathrm{III}}$ interatomic distances. As expected based on the $\sim 0.15 \AA$ increase in $\mathrm{Ac}^{\mathrm{III}}$ six coordinate ionic radii, the $\mathrm{An}^{\mathrm{III}}$ $\mathrm{O}_{\mathrm{H}_{2} \mathrm{O}}$ and $\mathrm{An}^{\mathrm{III}}-\mathrm{O}_{\mathrm{NO}_{3} \text { (bound) }}$ distances increased by approximately $0.2 \AA$ from $\mathrm{Cm}^{\mathrm{III}}$ and $\mathrm{Am}^{\mathrm{III}}$ to $\mathrm{Ac}^{\mathrm{III}}$.

Because EXAFS spectroscopy probes all species in solution, it does not exclude $\mathrm{An}^{\mathrm{III}}$ access to other stoichiometric ratios of $\mathrm{NO}_{3}{ }^{-}$and $\mathrm{H}_{2} \mathrm{O}$, Scheme 2. Instead, it provides an average signal from all of the molecules in the sample. In this context, good models of the data were only obtained with $\eta^{2}-\mathrm{NO}_{3}{ }^{-}$ligands (bidentate), which were consistent with many models previously reported for lanthanide and actinide EXAFS data.50,56-58 One notable exception was identified by Antonio and coworkers. These authors successfully identified monodentate $\eta^{1}-\mathrm{NO}_{3}{ }^{-}$ binding for $\mathrm{Ce}^{\mathrm{III}}$ in $3 \mathrm{M} \mathrm{HNO}_{3}$, a notably lower concentration than the $16 \mathrm{M} \mathrm{HNO}_{3}$ discussed here. ${ }^{59}$ Our attempts to introduce $\eta^{1}-\mathrm{NO}_{3}{ }^{-}$(monodentate) binding increased the $\mathrm{An}^{\mathrm{III}} \rightarrow$ $\mathrm{N}_{\mathrm{NO}_{3}}$ and $\mathrm{An}^{\mathrm{III}} \rightarrow \mathrm{O}_{\mathrm{NO}_{3} \text { (terminal) distances into unrealistic regions }}$ of the spectra where no intensity was present. Additionally, $\eta^{1}$ $\mathrm{NO}_{3}{ }^{-}$diminished the amplitude for linear multiple scattering pathways, giving an appreciable misfit between $3<R<4.5 \AA$ in the Fourier transform. We interpret these results as suggesting that in $16 \mathrm{M} \mathrm{HNO}_{3} \mathrm{An}^{\mathrm{III}}-\eta^{2}-\mathrm{NO}_{3}$ binding was preferred for $\mathrm{Cm}^{\mathrm{III}}, \mathrm{Am}^{\mathrm{III}}$, and $\mathrm{Ac}^{\mathrm{III}}$ over monodentate modes, likely due to the chelation effect. ${ }^{60}$ Consistent with this observation were quantum calculations on $\mathrm{M}\left(\mathrm{NO}_{3}\right)_{x}\left(\mathrm{H}_{2} \mathrm{O}\right)_{y}{ }^{3-x}\left(\mathrm{M}=\mathrm{Am}^{\mathrm{III}}, \mathrm{Eu}^{\mathrm{III}}\right)$ reported by $\mathrm{Xi}$ and coworkers. ${ }^{61}$ Their calculations predicted that $\eta^{2}-\mathrm{NO}_{3}$ binding was preferred energetically in aqueous solutions, especially when the first coordination shell was sterically saturated. Xi's calculated $2.45 \AA \mathrm{Am}-\left[\eta^{2}-\mathrm{O}_{\mathrm{NO}_{3} \text { (bound) }}\right]$ bond distance is in excellent agreement with our EXAFS results, lending confidence to our $\eta^{2}-\mathrm{NO}_{3}$ binding model. As pointed out to us privately by Antonio, the larger $\mathrm{An}-\mathrm{NO}_{3}{ }^{-}$stability constants $^{62}$ may be responsible for $\mathrm{Cm}^{\mathrm{III}}, \mathrm{Am}^{\mathrm{III}}$, and $\mathrm{Ac}^{\mathrm{III}}$ preference for $\eta^{2}-\mathrm{NO}_{3}{ }^{-}$binding. ${ }^{59,63}$

For experiments conducted at the intermediate $\mathrm{HNO}_{3}$ concentration ( $4 \mathrm{M}$ ), an alternative fitting method was pursued. The initial model was generated from a linear combination of the two end members, namely $\mathrm{An}^{\mathrm{III}}$ dissolved in 0.05 and $16 \mathrm{M}$ $\mathrm{HNO}_{3}$. This fit (Fig. 4) suggested that the $4 \mathrm{M} \mathrm{HNO}_{3} \mathrm{Cm}^{\mathrm{III}}$ speciation could be described as containing $73.6(1.8) \%$ of the $\mathrm{Cm}^{\mathrm{III}}$ aquo ion and $26.4(1.8) \%$ of the $\mathrm{Cm}\left(\mathrm{NO}_{3}\right)_{4.1 \pm 0.7}\left(\mathrm{H}_{2}-\right.$ O) ${ }_{5.7 \pm 1.3^{(1.1 \pm 0.2)}-}$ (Fig. 5). The slightly larger $\mathrm{Am}^{\mathrm{III}}$ cation gave a similar ratio; $67.4(1.4) \%$ of the $\mathrm{Am}^{\mathrm{III}}$ aquo and $32.6(1.4) \%$ $\mathrm{Am}\left(\mathrm{NO}_{3}\right)_{3.4 \pm 0.7}\left(\mathrm{H}_{2} \mathrm{O}\right)_{5.4 \pm 0.5}(0.4 \pm 0.1)-$. More substantial differences were observed when moving to the much bigger $\mathrm{Ac}^{\mathrm{III}}$ ion. The analysis showed $60.5(1.4) \%$ of the $\mathrm{Ac}^{\mathrm{III}}$ aquo and $39.5(1.4) \%$ of the $\mathrm{Ac}\left(\mathrm{NO}_{3}\right)_{2.3 \pm 1.7}\left(\mathrm{H}_{2} \mathrm{O}\right)_{8.3 \pm 5.2}{ }^{(0.7 \pm 0.5)+}$. These analyses assisted subsequent modeling efforts that used shell-by-shell

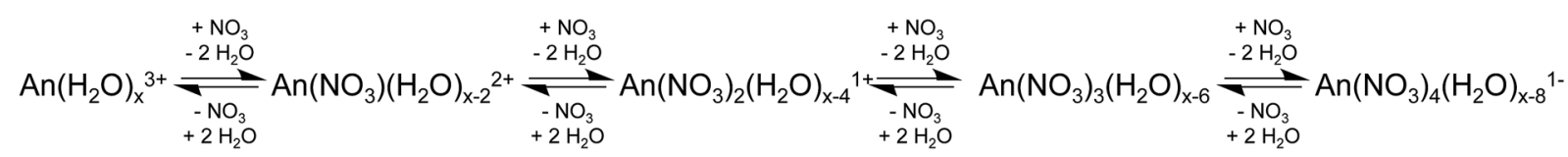

Scheme 2 Various actinide nitrate speciation possibilities. 


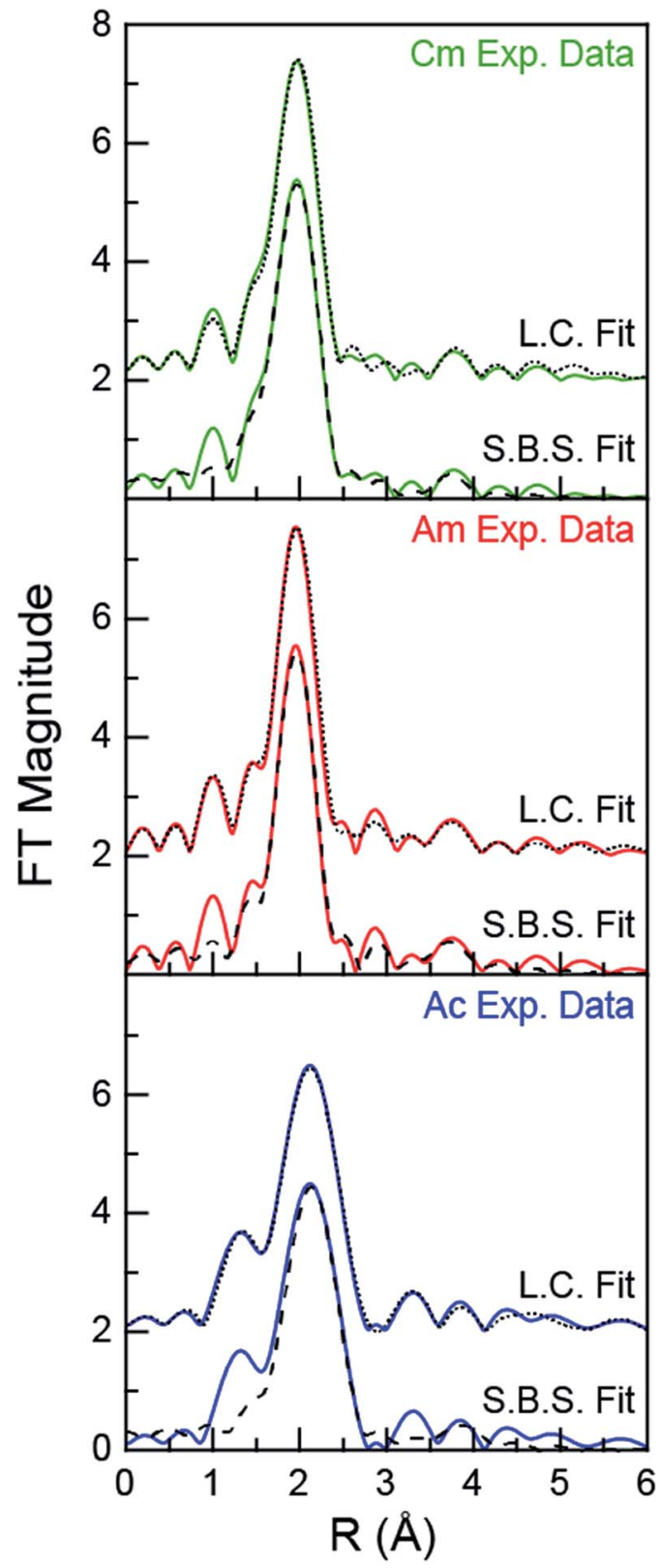

Fig. 4 Fourier transform of the $A n^{\prime \prime \prime} L_{3}$-edge $k^{3}$-EXAFS spectra of $A n^{\prime \prime \prime}$ dissolved in $4 \mathrm{M} \mathrm{HNO}_{3}\left(\mathrm{An}=\mathrm{Cm}^{\prime \prime \prime}\right.$, top; $\mathrm{Am}^{\prime \prime \prime}$, middle; $\mathrm{Ac}^{\prime \prime \prime}$, bottom). Experimental data are shown as green, red and blue traces (for $\mathrm{Cm}^{\prime \prime \prime}$, $A m^{\prime \prime \prime}$, and $A C^{\prime \prime \prime}$, respectively), linear combination fitting (L.C. Fit) results are shown as a dotted black trace, and shell-by-shell fitting (S.B.S. Fit) results are shown as a dashed black trace.

methods, similar to those described above to fit the 0.05 and $16 \mathrm{M} \mathrm{HNO}_{3}$ spectra. The fitting routine for the $\mathrm{HNO}_{3}(4 \mathrm{M})$ data differed in that it included all of the scattering pathways used in the 0.05 and $16 \mathrm{M}$ models. To keep the number of fitted parameters less than half of the total number of independent variables, ${ }^{64}$ the coordination numbers were fixed in accordance with the percentages determined from the linear combination analyses (Fig. 4 and 5). Under these conditions, variables associated with the interatomic distance $(R)$ and Debye-Waller factors $\left(\sigma^{2}\right)$ were allowed to converge to reasonable values, as

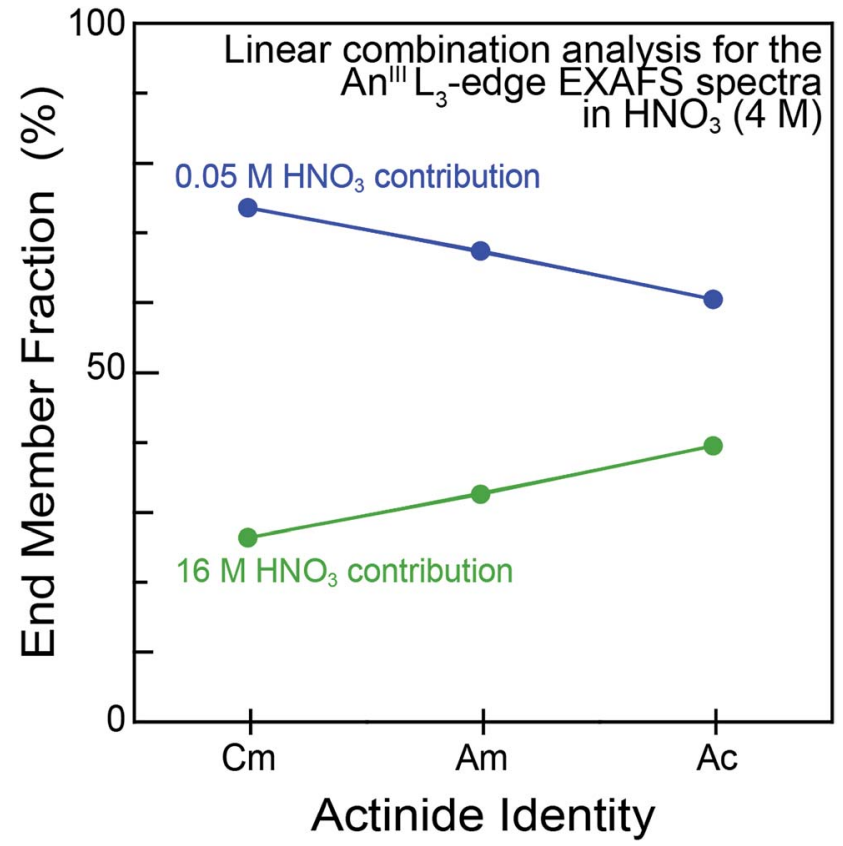

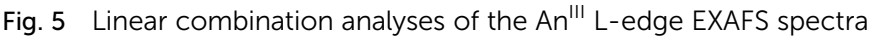
of $A n^{\prime \prime \prime}$ cations dissolved in $\mathrm{HNO}_{3}\left(4 \mathrm{M} ; \mathrm{An}^{\prime \prime \prime}=\mathrm{Cm}^{\prime \prime \prime}, \mathrm{Am}^{\text {III }}\right.$ and $\left.\mathrm{Ac} \mathrm{C}^{\text {III }}\right)$. The end member identities were obtained from fits to the $A c^{\prime \prime \prime} L_{3}$-edge EXAFS spectra from dilute $(0.05 \mathrm{M}$; blue trace) vs. concentrated (16 M; green trace) $\mathrm{HNO}_{3}$ solutions.

shown in Table 2. The good agreement of these shell-by-shell fits with the experimental data validated conclusions from the linear combination analyses, suggesting that the $\mathrm{H}_{2} \mathrm{O}$ and $\mathrm{NO}_{3}{ }^{-}$ coordination numbers were between those of the 0.05 and $16 \mathrm{M}$ end-members.

\section{Outlook}

The $\mathrm{An}^{\mathrm{III}} \mathrm{L}_{3}$-edge XAS results described herein represent a humble contribution to the growing body of knowledge associated with $\mathrm{Cm}^{\mathrm{III}}, \mathrm{Am}^{\mathrm{III}}$, and $\mathrm{Ac}^{\mathrm{III}}$ coordination chemistry, aqueous speciation, and chemical reactivity. ${ }^{10-21,65-69}$ To most effectively communicate the significance of these results, we find it instructive to present the data within the context of some relevant studies reported for $\mathrm{NO}_{3}{ }^{-}$binding of $\mathrm{Cm}^{\mathrm{III}}, \mathrm{Am}^{\mathrm{III}}$, and $\mathrm{Ac}^{\mathrm{III}}$. For example, in the solid state, there are only two single crystal X-ray structures reported that contain $\mathrm{Am}-\mathrm{NO}_{3}$ bonds. In these complexes the $\mathrm{Am}-\mathrm{O}_{\mathrm{NO}_{3}}$ distances ranged from 2.514 to $2.635(12) \AA,^{70,71}$ which was in good agreement with our $\mathrm{Am}-\mathrm{O}_{\mathrm{NO}_{3}}$ results, 2.50(1) and 2.57(3). To date, we have been unaware of any $\mathrm{Cm}$ single crystal structures that contain $\mathrm{Cm}-\mathrm{NO}_{3}$ bonds and no single crystal data of any kind have been reported for Ac. Solutionphase characterization using EXAFS spectroscopy is equally sparse. There is a report from Den Auwer on the $\mathrm{Am}\left(\mathrm{NO}_{3}\right)_{3}$ (TEMA $)_{2}$ complex ${ }^{72}$ another by Girnt on $\mathrm{Am}\left(\mathrm{NO}_{3}\right)_{x}$ (dmpbipy $)_{x},{ }^{73}$ one by Bremer involving $\mathrm{Am}\left(\mathrm{NO}_{3}\right)_{x}(\mathrm{C} 5-\mathrm{BPP})_{x},{ }^{74}$ and finally Ekberg investigated $\left[\mathrm{Am}\left(\mathrm{NO}_{3}\right)\left(\mathrm{CyMe}_{4}-\mathrm{BTBP}\right)_{2}\right]^{2+} \cdot{ }^{75}$ These studies showed an average $\mathrm{Am}-\mathrm{O}_{\mathrm{NO}_{3}}$ distance of $2.49 \pm 0.01 \AA$. For $\mathrm{Cm}$, numerous measurements have been made on $\mathrm{NO}_{3}{ }^{-}$species. These include 
(but are not limited to) time resolved laser fluorescence and luminescence measurements made on $\mathrm{Cm}^{\mathrm{III}}$ in nitrate containing solutions, ${ }^{11,76,77}$ numerous studies documenting the extraction of $\mathrm{Cm}^{\mathrm{III}}$ from $\mathrm{HNO}_{3}$ solutions, ${ }^{78-81}$ as well as thermal decomposition of $\mathrm{Cm}^{\mathrm{III}}\left(\mathrm{NO}_{3}\right)_{3}{ }^{\mathbf{8 2 , 8 3}}$ For $\mathrm{Cm}$ we are unaware of EXAFS measurements made in $\mathrm{HNO}_{3}$ solutions and for Ac the $\mathrm{Ac}-\mathrm{NO}_{3}{ }^{-}$interaction has not been characterized previously.

In the context of what is understood regarding complexation of $\mathrm{Cm}^{\mathrm{III}}, \mathrm{Am}^{\mathrm{III}}$, and $\mathrm{Ac}^{\mathrm{III}}$ by $\mathrm{NO}_{3}{ }^{-}$in aqueous media, the EXAFS results reported herein provide hard data that can be used broadly to assist applied and fundamental efforts that require $\mathrm{An}^{\mathrm{III}}$ cations to be dissolved in $\mathrm{HNO}_{3(\mathrm{aq})}$. Our data suggested that $\mathrm{Cm}^{\mathrm{III}}, \mathrm{Am}^{\mathrm{III}}$, and $\mathrm{Ac}^{\mathrm{III}}$ existed as aquo ions in dilute $\mathrm{HNO}_{3}$ matrices $(0.05 \mathrm{M})$. These results agreed with the small $\mathrm{An}^{\mathrm{III}}-\mathrm{NO}_{3}$ stability constants: ([ $\left.\mathrm{An}^{\mathrm{III}}-\mathrm{NO}_{3}\right] /\left[\mathrm{An}^{\mathrm{III}}\right]\left[\mathrm{NO}_{3}{ }^{-}\right]$; $\log K$, ionic strength $\left.=1 \mathrm{M}, 25^{\circ} \mathrm{C}\right) 0.34\left(\mathrm{Cm}^{\mathrm{III}}\right),{ }^{84} 0.25 \pm 0.02$ $\left(\mathrm{Am}^{\mathrm{III}}\right),{ }^{85}$ and $0.1\left(\mathrm{Ac}^{\mathrm{III}}\right) .{ }^{85}$ Along these lines, Choppin and coworkers used $\mathrm{Cm}^{\mathrm{III}}$ fluorescence to evaluate $\mathrm{NO}_{3}{ }^{-}$ complexation in aqueous solutions with varied $\mathrm{HNO}_{3}$ concentrations. In this study, moving from 0.1 to $13 \mathrm{MHNO}_{3}$ decreased the number of bound $\mathrm{H}_{2} \mathrm{O}$ molecules, presumably accompanied by $\mathrm{NO}_{3}{ }^{-}$complexation. A total of four $\mathrm{H}_{2} \mathrm{O}$ molecules were reportedly removed in $13 \mathrm{M} \mathrm{HNO}_{3}$, suggesting that a bis-nitrato $\left[\mathrm{M}\left(\mathrm{NO}_{3}\right)_{2}\left(\mathrm{H}_{2} \mathrm{O}\right)_{5}\right]^{1+}$ complex had formed. ${ }^{86}$ Consistent with Choppin and coworkers' results, ${ }^{\mathbf{8 6}}$ our EXAFS data showed that nitrate complexation for $\mathrm{Cm}^{\mathrm{III}}$, $\mathrm{Am}^{\mathrm{III}}$, and $\mathrm{Ac}^{\mathrm{III}}$ increased with increasing $\mathrm{HNO}_{3}$ concentration. In $4 \mathrm{M}$ $\mathrm{HNO}_{3}$, we observed approximately one inner sphere $\mathrm{NO}_{3}{ }^{-}$. Moving past Choppin and Coworkers' $13 \mathrm{M} \mathrm{HNO}_{3}$ to concentrated $\mathrm{HNO}_{3}(16 \mathrm{M})$, increased the number of coordinated $\mathrm{NO}_{3}{ }^{-}$ligands, ranging from $4.1 \pm 0.7$ for $\mathrm{Cm}^{\mathrm{III}}$, to $3.4 \pm$ 0.7 for $\mathrm{Am}^{\mathrm{III}}$, and $2.3 \pm 1.7$ for $\mathrm{Ac}^{\mathrm{III}}$. It is interesting that the $\mathrm{NO}_{3}{ }^{-}$coordination numbers seemed to decrease with increasing metal ionic radius. While tempting to correlate these results with the stability constants referenced above and with the Lewis acidity for the $\mathrm{An}^{\mathrm{III}}$ cations, we refrain since the $\mathrm{NO}_{3}{ }^{-}$coordination numbers were equivalent when the uncertainties for the measurements were considered.

In terms of structural characterization, the $\mathrm{Ac}^{\mathrm{III}}-\mathrm{O}_{\mathrm{H}_{2} \mathrm{O}}$ and

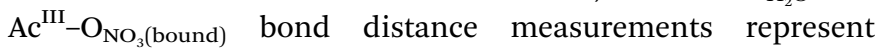
another impactful component of this manuscript. Prior to these experiments, there were two reported $\mathrm{Ac}-\mathrm{O}_{\mathrm{H}_{2} \mathrm{O}}$ bond distances, both measured by solution-phase $\mathrm{Ac}^{\mathrm{III}} \mathrm{L}_{3}$-edge EXAFS spectroscopy. One was in concentrated $\mathrm{HCl}(11 \mathrm{M})$ solutions $(2.59 \pm$ $0.03 \AA)^{21}$ and the other in dilute $\mathrm{HO}_{3} \mathrm{SCF}_{3}(0.11 \mathrm{M} ; 2.63 \pm 0.01$ $\AA) .{ }^{12}$ Contributed here are three additional $\mathrm{Ac}-\mathrm{O}_{\mathrm{H}_{2} \mathrm{O}}$ measurements; $2.63 \pm 0.02\left(0.05 \mathrm{M} \mathrm{HNO}_{3}\right), 2.61 \pm 0.02\left(4 \mathrm{M} \mathrm{HNO}_{3}\right)$, and $2.70 \pm 0.02\left(16 \mathrm{M} \mathrm{HNO}_{3}\right)$. This brings the total number of reported Ac- $\mathrm{O}_{\mathrm{H}_{2} \mathrm{O}}$ bond distances to five, averaging $2.63 \pm 0.04 \AA$ (error reported as the standard deviation of the mean, $1 \sigma$ ). Their consistency provides confidence in the accuracy of these $\mathrm{Ac}^{\mathrm{III}} \mathrm{L}_{3}$-edge EXAFS measurements. In terms of $\mathrm{NO}_{3}{ }^{-}$ complexation, these results are also exciting as they represent the first $\mathrm{Ac}^{\mathrm{III}}-\mathrm{NO}_{3}{ }^{-}$interaction observed spectroscopically. Although the $\mathrm{Ac}^{\mathrm{III}}-\mathrm{O}_{\mathrm{NO}_{3}}$ distance was not resolved from the inner-sphere $\mathrm{Ac} c^{\mathrm{III}}-\mathrm{O}_{\mathrm{H}_{2} \mathrm{O}}$ interaction, the $\mathrm{Ac} \mathrm{c}^{\mathrm{III}}-\mathrm{O}_{\mathrm{NO}_{3}}$ bond length can be indirectly inferred based on the measured $\mathrm{Ac}^{\mathrm{III}}-\mathrm{N}_{\mathrm{NO}_{3}}$

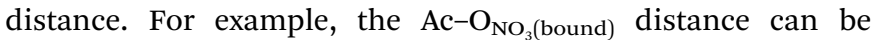
calculated using the cosine rule; assuming an average $\mathrm{N}-\mathrm{O}$ distance of $1.31 \AA$ and an average Ac-N-O angle of $113^{\circ} .{ }^{57}$ This analysis gives an $\mathrm{Ac}^{\mathrm{III}}-\mathrm{O}_{\mathrm{NO}_{3}}$ distance of $2.70 \pm 0.10 \AA$.

In terms of fundamental exploratory science, the chemistry of $\mathrm{Cm}^{\mathrm{III}}, \mathrm{Am}^{\mathrm{III}}$, and $\mathrm{Ac}^{\mathrm{III}}$ presents uncharted landscapes in comparison to many other elements in the periodic table. Unique safety hazards and limited access to sizable quantities of material represent significant technical challenges faced during experimental studies of these elements. Even interactions with common ligands - such as the $\mathrm{An}-\mathrm{H}_{2} \mathrm{O}$ and An$\mathrm{NO}_{3}$ bonds - are poorly defined. On top of scientific curiosity is the need to support innovation for $\mathrm{An}^{\mathrm{III}}$ processing. This need includes developing advanced nuclear fuel cycles, medical isotope production, and targeted alpha therapy. It seems likely that our approach for characterizing $\mathrm{An}-\mathrm{NO}_{3}$ and $\mathrm{An}-\mathrm{H}_{2} \mathrm{O}\left(\mathrm{An}=\mathrm{Cm}^{\mathrm{III}}, \mathrm{Am}^{\mathrm{III}}, \mathrm{Ac}^{\mathrm{III}}\right)$ interactions using $\mathrm{An}^{\mathrm{III}}$ $\mathrm{L}_{3}$-edge EXAFS can be broadly applied to other $\mathrm{An}^{\mathrm{III}}$-ligands interactions, which are equally relevant for nuclear processing and medical applications. We hope that the results presented herein will provide insight aiding our current efforts - as well as those associated with other researchers embarking on their own fundamental and applied scientific campaigns - to solve complicated technical problems associated with $\mathrm{Cm}^{\mathrm{III}}, \mathrm{Am}^{\mathrm{III}}$, and $\mathrm{Ac}^{\mathrm{III}}$.

\section{Experimental section}

\section{General consideration}

Caution! The ${ }^{246 / 248} \mathrm{Cm}\left[t_{1 / 2}=4706(40)\right.$ years $/ 3.48(6) \times 10^{5}$ years $],{ }^{87}{ }^{243} \mathrm{Am}\left[t_{1 / 2}=7364(22)\right.$ years $],{ }^{87}$ and ${ }^{227} \mathrm{Ac}\left[t_{1 / 2}=\right.$ 21.772(3) years $]^{87}$ isotopes present serious health threats due to their (as well as their daughters) direct neutron-, $\alpha-, \beta$-, and $\gamma^{-}$ emissions of their radioactive daughters. Hence, all studies that involved uncontained manipulations were conducted in a radiation laboratory equipped with HEPA filtered hoods, continuous air monitors, negative pressure gloveboxes, and monitored equipment appropriate neutron-, $\alpha-, \beta$-, and $\gamma$ particle detection. All free-flowing solids were handled within negative pressure gloveboxes equipped with HEPA filters. The ${ }^{246 / 248} \mathrm{Cm},{ }^{243} \mathrm{Am}$, and ${ }^{227} \mathrm{Ac}$ isotopes were supplied by the United States Department of Energy Office of Science Isotope Program in the Office of Nuclear Physics. Chemically pure $\mathrm{Cm}^{\mathrm{III}}, \mathrm{Am}^{\mathrm{III}}$, and $\mathrm{Ac}^{\mathrm{III}}$ stock solutions were prepared as previously described. ${ }^{\mathbf{1 2 , 2 0 , 3 1}}$ Optima grade nitric acid was obtained commercially (Fisher Scientific). Water was purified to 18.2 $\mathrm{M} \Omega \mathrm{cm}^{-1}$ resistivity using Thermo-Scientific Barnstead Nanopure or Millipore Nanopure water purification systems. For $\mathrm{Ac}^{\mathrm{III}}$, the water was further purified by using a Teflon distilling apparatus.

\section{Sample preparation}

Three solution-phase XAS samples were prepared for each element. The first was prepared in $0.05 \mathrm{M} \mathrm{HNO}_{3}$, the second in $4 \mathrm{M} \mathrm{HNO}_{3}$ and the third in $16 \mathrm{M}$ (concentrated) $\mathrm{HNO}_{3}$. To prepare the samples, aliquots from purified $\mathrm{Cm}^{\mathrm{III}}(0.5 \mathrm{mg} ; 2.02$ 
$\mu \mathrm{mol}), \mathrm{Am}^{\mathrm{III}}(0.5 \mathrm{mg} ; 2.06 \mu \mathrm{mol})$, and $\mathrm{Ac}^{\mathrm{III}}(28 \mu \mathrm{g} ; 0.123 \mu \mathrm{mol})$ stock solutions were transferred to conical glass vials. The aqueous solution was removed by heating the samples on a hot plate at around $110{ }^{\circ} \mathrm{C}$ under a flow of argon gas until soft dryness was achieved. The residue was dissolved in aqueous nitric acid of desired molarity. Each sample was boiled and dissolved three times to ensure that the $\mathrm{HNO}_{3}$ concentration was actually $0.05,4$, or $16 \mathrm{M}$. The solution volumes for each sample were $0.5 \mathrm{~mL}(\mathrm{Am}), 0.5 \mathrm{~mL}(\mathrm{Cm})$, and 0.3 (Ac). The resulting solutions were transferred to an XAS holder.

\section{Radiological containment for XAS samples}

The XAS holders and handling procedures provided adequate containment (three layers) and administrative/engineering controls that guarded against release of radiological material during shipment and during data acquisition. The holder consisted of a plastic body with a $5 \mathrm{~mm}$ well for $\mathrm{Cm}^{\mathrm{III}}$ and $\mathrm{Am}^{\mathrm{III}}$ and a $2 \mathrm{~mm}$ well for $\mathrm{Ac}^{\mathrm{III}}$ equipped with a set of Teflon windows (1 mil) and a Kapton window (1 mil). Solutions were introduced into the holder through an injection hole sealed with a Teflon gasket that was held in place by an aluminum plate. This primary holder was then held within a secondary container, which in turn was held within the tertiary container. The secondary and tertiary containers are best described as a set of nested aluminum holders equipped with Kapton windows (2 mil) and rubber gaskets.

\section{XAS data acquisition}

The actinide $\mathrm{L}_{3}$-edge XANES and EXAFS measurements were made at the Stanford Synchrotron Radiation Lightsource (SSRL) under dedicated operating conditions $(3.0 \mathrm{GeV}, 5 \%, 500 \mathrm{~mA})$ on end station 11-2. This beamline was equipped with a 26-pole and a 2.0 tesla wiggler. Using a liquid nitrogen-cooled double-crystal $\operatorname{Si}(220)\left(\Phi=0^{\circ}\right.$ for $\mathrm{Cm}^{\mathrm{III}} ; \Phi=90^{\circ}$ for $\mathrm{Am}^{\mathrm{III}}$ and $\left.\mathrm{Ac}^{\mathrm{III}}\right)$ monochromator and employing collimating and focusing mirrors, a single energy was selected from the incident white beam. Vertical acceptance was controlled by slits positioned before the monochromator. For $\mathrm{Cm}^{\mathrm{III}}$, the monochromator crystals were $35 \%$ detuned. Meanwhile, $\mathrm{Am}^{\mathrm{III}}$ and $\mathrm{Ac}^{\mathrm{III}} \mathrm{L}_{3}$-edge measurements were conducted with the monochromator crystals fully-tuned. For these experiments, higher harmonics from the monochromatic light were removed using a $370 \mathrm{~mm}$ Rh coated harmonic rejection mirror. The Rh coating was $50 \mathrm{~nm}$ with a $20 \mathrm{~nm}$ seed coating and the substrate was Zerodur. The harmonic rejection cut-off was set by the mirror angle, controlling which photons experience total external reflection. The samples were attached to the beamline 112 XAS rail. The rail was equipped with three ionization chambers through which nitrogen gas was continually flowed. One chamber was positioned before the sample holder to monitor the incident radiation $\left(I_{0}, 10 \mathrm{~cm}\right)$. The second chamber was positioned after the sample holder, such that sample transmission $\left(I_{1}, 30 \mathrm{~cm}\right)$ could be evaluated against $I_{0}$, while a third chamber $\left(I_{2}, 30 \mathrm{~cm}\right)$ was positioned downstream from $I_{1}$ so that the XANES of a calibration foil could be measured in situ during the XAS experiments against $I_{1}$. All actinide $\mathrm{L}_{3}$-edge XAS spectra were measured by monitoring sample fluorescence against the incident radiation
$\left(I_{0}\right)$. The detector was positioned $90^{\circ}$ to the incident radiation $\left(I_{0}\right)$. For $\mathrm{Cm}^{\mathrm{III}}$ and $\mathrm{Am}^{\mathrm{III}}$ a Lytle detector, equipped with Soller slits and $\mathrm{Sr}$ (3 absorption lengths) filters were used. For $\mathrm{Ac}^{\mathrm{III}}$ measurements, a solid-state 100-element Ge detector was used. This detector was windowed on the $\mathrm{Ac}^{\mathrm{III}} \mathrm{L} \alpha_{1}$-emission line (12.652 $\mathrm{keV})$. High-energy contributions to the fluorescence signal were removed using a bromine filter (6 absorption lengths). Using a Se filter, detector dead time was characterized approximately $400 \mathrm{eV}$ above the Se K-edge by defining the detector response from 0 to $\sim 70 \%$ dead (windowed counts of the emission line versus the total of incoming counts in the solid-state detector).

\section{XAS data analysis}

Data manipulation and analysis was conducted as previously described. ${ }^{21,43}$ All calibration spectra were measured in situ. The $\mathrm{Cm}^{\mathrm{III}}$ and $\mathrm{Am}^{\mathrm{III}}$ spectra were calibrated to the energy of the absorption peak maximum of a $\mathrm{Zr}$ foil (18 $013.3 \mathrm{eV}$ (ref. 88)). The actinium sample data were dead time corrected and calibrated to the energy of the first inflection point of a rubidium(II) chloride, $\mathrm{RbCl}$, pellet diluted with boron nitride (BN) to a 1 absorption length thickness. The energy for the first inflection point for $\mathrm{RbCl}$ was determined in comparison to the $\mathrm{Bi}_{2}$-edge of a bismuth foil (15 711 eV) to be $15203.8 \mathrm{eV}$.

The XAS data were analyzed by fitting a line to the pre-edge region, which removed the background from experimental data in the spectra. Then a third order polynomial fit was chosen for the post-edge region. The difference between pre and post edge lines was set to unity at the first inflection point, normalizing the absorption jump to 1.0. Samples were measured for several hours resulting in the collection of multiple scans. The EXAFS data were analyzed by either shellby-shell fitting methods using IFEFFIT software ${ }^{88}$ and FEFF8 calculations $^{\mathbf{4 4 , 4 5}}$ or linear combination analyses (IFEFFIT). ${ }^{\mathbf{8}}$ Atomic coordinates for the FEFF8 calculations were obtained by geometry optimizations generated from DFT calculations (see below). Data were fit over the following ranges; for curium and americium $2.7<k<11 \AA^{-1}$ and $1.1<R<4.5 \AA$ (to $3 \AA$ for $0.05 \mathrm{M}$ ) and for actinium $2.7<k<9.5 \AA^{-1}$ and $1.25<R<4.5 \AA$.

\section{DFT calculations}

All DFT calculations were performed with ORCA version 4.0.1. ${ }^{89}$ Calculations utilized the PBE functional, ${ }^{90}$ the SARC-ZORATZVP $^{91,92}$ and def2 (ref. 93) basis sets, and the D3 dispersion corrections. ${ }^{\mathbf{9 4}, 95}$ Coordinates of the DFT optimized structures are given in the ESI. $\dagger$

\section{Conflicts of interest}

There are no conflicts to declare.

\section{Acknowledgements}

We would like to thank Dr Mark R. Antonio for thought provocative discussions that motivated this research and for his guidance in preparing this manuscript. The Am and Cm work was funded under the Heavy Element Chemistry Program by the 
Division of Chemical Sciences, Geosciences, and Biosciences, Office of Basic Energy Sciences, U.S. Department of Energy and the U.S. Department of Energy. All Ac work in this article was supported by the Laboratory Directed Research and Development program of Los Alamos National Laboratory under project number [20180005DR]. Portions of this work were supported by postdoctoral fellowships from the Glenn T. Seaborg Institute (Ferrier, Stein), the distinguished Darleane Christian Hoffman Fellowship (Cary), and the Agnew National Security Fellowship (Bone). Los Alamos National Laboratory is operated by Los Alamos National Security, LLC, for the National Nuclear Security Administration of U.S. Department of Energy (contract DEAC52-06NA25396). We gratefully recognize the United States Department of Energy, Office of Science, Isotope Development and Production for Research and Application subprogram within Office of Nuclear Physics for their support in supplying the ${ }^{246,248} \mathrm{Cm},{ }^{243} \mathrm{Am}$, and ${ }^{227} \mathrm{Ac}$ isotopes. Use of the Stanford Synchrotron Radiation Lightsource, SLAC National Accelerator Laboratory, was supported by the U.S. Department of Energy, Office of Science, Office of Basic Energy Sciences under Contract No. DE-AC02-76SF00515.

\section{References}

1 Y. S. Kim and M. W. Brechbiel, Tumor Biol., 2012, 33, 573590.

2 D. A. Mulford, D. A. Scheinberg and J. G. Jurcic, J. Nucl. Med., 2005, 46, 199S-204S.

3 B. J. Allen, C. Raja, S. Rizvi, Y. Li, W. Tsui, D. Zhang, E. Song, C. F. Qu, J. Kearsley, P. Graham and J. Thompson, Phys. Med. Biol., 2004, 49, 3703-3712.

4 D. Warin, IOP Conf. Ser.: Mater. Sci. Eng., 2010, 9, 012063.

5 J. C. Braley, D. R. McAlister, E. Philip Horwitz and K. L. Nash, Solvent Extr. Ion Exch., 2013, 31, 107-121.

6 I. A. Shkrob, T. W. Marin and M. P. Jensen, Ind. Eng. Chem. Res., 2014, 53, 3641-3653.

7 A. V. Gelis and G. J. Lumetta, Ind. Eng. Chem. Res., 2014, 53, 1624-1631.

8 B. J. Mincher, N. C. Schmitt, R. D. Tillotson, G. Elias, B. M. White and J. D. Law, Solvent Extr. Ion Exch., 2014, 32, 153-166.

9 M. Carrott, A. Geist, X. Hères, S. Lange, R. Malmbeck, M. Miguirditchian, G. Modolo, A. Wilden and R. Taylor, Hydrometallurgy, 2015, 152, 139-148.

10 R. M. Diamond, K. Street Jr. and G. T. Seaborg, J. Am. Chem. Soc., 1954, 76, 1461-1469.

11 B. Gannaz, R. Chiarizia, M. R. Antonio, C. Hill and G. Cote, Solvent Extr. Ion Exch., 2007, 25, 313-337.

12 M. G. Ferrier, B. W. Stein, E. R. Batista, J. M. Berg, E. R. Birnbaum, J. W. Engle, K. D. John, S. A. Kozimor, J. S. Lezama Pacheco and L. N. Redman, ACS Cent. Sci., 2017, 3, 176-185.

13 M. P. Kelley, J. Su, M. Urban, M. Luckey, E. R. Batista, P. Yang and J. C. Shafer, J. Am. Chem. Soc., 2017, 139, 9901-9908.

14 B. J. Mincher, L. R. Martin and N. C. Schmitt, Inorg. Chem., 2008, 47, 6984-6989.
15 S. R. Daly, J. M. Keith, E. R. Batista, K. S. Boland, D. L. Clark, S. A. Kozimor and R. L. Martin, J. Am. Chem. Soc., 2012, 134, 14408-14422.

16 G. L. Law, C. M. Andolina, J. Xu, V. Luu, P. X. Rutkowski, G. Muller, D. K. Shuh, J. K. Gibson and K. N. Raymond, J. Am. Chem. Soc., 2012, 134, 15545-15549.

17 T. F. Wall, S. Jan, M. Autillo, K. L. Nash, L. Guerin, C. Le Naour, P. Moisy and C. Berthon, Inorg. Chem., 2014, 53, 2450-2459.

18 M. P. Jensen, R. Chiarizia, I. A. Shkrob, J. S. Ulicki, B. D. Spindler, D. J. Murphy, M. Hossain, A. Roca-Sabio, C. Platas-Iglesias, A. De Blas and T. Rodríguez-Blas, Inorg. Chem., 2014, 53, 6003-6012.

19 M. J. Polinski, K. A. Pace, J. T. Stritzinger, J. Lin, J. N. Cross, S. K. Cary, S. M. Van Cleve, E. V. Alekseev and T. E. AlbrechtSchmitt, Chem.-Eur. J., 2014, 20, 9892-9896.

20 J. N. Cross, J. A. Macor, J. A. Bertke, M. G. Ferrier, G. S. Girolami, S. A. Kozimor, J. R. Maassen, B. L. Scott, D. K. Shuh, B. W. Stein and S. C. E. Stieber, Angew. Chem., Int. Ed., 2016, 55, 12755-12759.

21 M. G. Ferrier, E. R. Batista, J. M. Berg, E. R. Birnbaum, J. N. Cross, J. W. Engle, H. S. La Pierre, S. A. Kozimor, J. S. Lezama Pacheco, B. W. Stein, S. C. E. Stieber and J. J. Wilson, Nat. Commun., 2016, 1-8.

22 S. Hotoku, T. Asakura, H. Mineo and G. Uchiyama, J. Nucl. Sci. Technol., 2002, 39, 313-316.

23 K. Bell, A. Geist, F. McLachlan, G. Modolo, R. Taylor and A. Wilden, Procedia Chem., 2012, 7, 152-159.

24 G. J. Lumetta, T. G. Levitskaia, A. Wilden, A. J. Casella, G. B. Hall, L. Lin, S. I. Sinkov, J. D. Law and G. Modolo, Solvent Extr. Ion Exch., 2017, 35, 377-395.

25 V. Radchenko, J. W. Engle, J. J. Wilson, J. R. Maassen, F. M. Nortier, W. A. Taylor, E. R. Birnbaum, L. A. Hudston, K. D. John and M. E. Fassbender, J. Chromatogr. A, 2015, 1380, 55-63.

26 R. A. Aliev, S. V. Ermolaev, A. N. Vasiliev, V. S. Ostapenko, E. V. Lapshina, B. L. Zhuikov, N. V. Zakharov, V. V. Pozdeev, V. M. Kokhanyuk, B. F. Myasoedov and S. N. Kalmykov, Solvent Extr. Ion Exch., 2014, 32, 468-477.

27 T. Mastren, V. Radchenko, A. Owens, R. Copping, R. Boll, J. R. Griswold, S. Mirzadeh, L. E. Wyant, M. Brugh, J. W. Engle, F. M. Nortier, E. R. Birnbaum, K. D. John and M. E. Fassbender, Sci. Rep., 2017, 7, 2-8.

28 B. Zielinska, C. Apostolidis, F. Bruchertseifer and A. Morgenstern, Solvent Extr. Ion Exch., 2007, 25, 339-349.

29 C. Apostolidis, R. Molinet, G. Rasmussen and A. Morgenstern, Anal. Chem., 2005, 77, 6288-6291.

30 R. A. Boll, D. Malkemus and S. Mirzadeh, Appl. Radiat. Isot., 2005, 62, 667-679.

31 S. K. Cary, J. Su, S. S. Galley, T. E. Albrecht-Schmitt, E. R. Batista, M. G. Ferrier, S. A. Kozimor, V. Mocko, B. L. Scott, B. W. Stein, F. D. White and P. Yang, Dalton Trans., 2018, manuscript submitted.

32 B. K. Teo, EXAFS: basic principles and data analysis, SpringerVerlag, New-York, Berlin, 1986.

33 J. Stohr, NEXAFS spectroscopy, Springer-Verlag, Berlin, 1st edn, 1992. 
34 S. K. Cary, M. Livshits, J. N. Cross, M. G. Ferrier, V. Mocko, B. W. Stein, S. A. Kozimor, B. L. Scott and J. J. Rack, Inorg. Chem., 2018, 57, 3782-3797.

35 S. A. Pattenaude, K. C. Mullane, E. J. Schelter, M. G. Ferrier, B. W. Stein, S. E. Bone, J. S. Lezama Pacheco, S. A. Kozimor, P. E. Fanwick, M. Zeller and S. C. Bart, Inorg. Chem., 2018, 57, 6530-6539.

36 F. Li, S. H. Carpenter, R. F. Higgins, M. G. Hitt, W. W. Brennessel, M. G. Ferrier, S. K. Cary, J. S. LezamaPacheco, J. T. Wright, B. W. Stein, M. P. Shores, M. L. Neidig, S. A. Kozimor and E. M. Matson, Inorg. Chem., 2017, 56, 7065-7080.

37 J. J. Kiernicki, M. G. Ferrier, J. S. Lezama Pacheco, H. S. La Pierre, B. W. Stein, M. Zeller, S. A. Kozimor and S. C. Bart, J. Am. Chem. Soc., 2016, 138, 13941-13951.

38 N. H. Anderson, S. O. Odoh, U. J. Williams, A. J. Lewis, G. L. Wagner, J. L. Pacheco, S. A. Kozimor, L. Gagliardi, E. J. Schelter and S. C. Bart, J. Am. Chem. Soc., 2015, 137, 4690-4700.

39 S. K. Cary, M. G. Ferrier, R. E. Baumbach, M. A. Silver, J. Lezama Pacheco, S. A. Kozimor, H. S. La Pierre, B. W. Stein, A. A. Arico, D. L. Gray and T. E. AlbrechtSchmitt, Inorg. Chem., 2015, 137(14), 4690-4700.

40 M. W. Löble, J. M. Keith, A. B. Altman, S. C. E. Stieber, E. R. Batista, K. S. Boland, S. D. Conradson, D. L. Clark, J. Lezama Pacheco, S. A. Kozimor, R. L. Martin, S. G. Minasian, A. C. Olson, B. L. Scott, D. K. Shuh, T. Tyliszczak, M. P. Wilkerson and R. A. Zehnder, J. Am. Chem. Soc., 2015, 137(14), 4690-4700.

41 M. E. Fieser, M. G. Ferrier, J. Su, E. Batista, S. K. Cary, J. W. Engle, W. J. Evans, J. S. Lezama Pacheco, S. A. Kozimor, A. C. Olson, A. J. Ryan, B. W. Stein, G. L. Wagner, D. H. Woen, T. Vitova and P. Yang, Chem. Sci., 2017, 8, 6076-6091.

42 R. D. Shannon, Acta Crystallogr., Sect. A: Found. Crystallogr., 1976, 32, 751-767.

43 S. Calvin, XAFS for everyone, CRC Press Tayor and Francis Group, 2013.

44 A. L. Ankudinov, B. Ravel, J. J. Rehr and S. D. Conradson, Phys. Rev. B, 1998, 58, 7565-7576.

45 J. J. Rehr, Rev. Mod. Phys., 2000, 72, 621-654.

46 P. G. Allen, J. J. Bucher, D. K. Shuh, N. M. Edelstein and I. Craig, Inorg. Chem., 2000, 39, 595-601.

47 S. Skanthakumar, M. R. Antonio, R. E. Wilson and L. Soderholm, Inorg. Chem., 2007, 46, 3485-3491.

48 P. Lindqvist-Reis, C. Apostolidis, J. Rebizant, A. Morgenstern, R. Klenze, O. Walter, T. Fanghänel and R. G. Haire, Angew. Chem., Int. Ed., 2007, 46, 919-922.

49 C. W. Kammeyer and D. R. Whitman, J. Chem. Phys., 1972, 56, 4419-4421.

50 T. Yaita, H. Narita, S. Suzuki, S. Tachimori, H. Motohashi and H. Shiwaku, J. Radioanal. Nucl. Chem., 1999, 239, 371-375.

51 R. Spezia, M. Duvail, P. Vitorge and P. D'Angelo, J. Phys.: Conf. Ser., 2009, 190, 0-6.

52 P. D'Angelo, A. Zitolo, V. Migliorati, G. Chillemi, M. Duvail, P. Vitorge, S. Abadie and R. Spezia, Inorg. Chem., 2011, 50, 4572-4579.
53 I. Persson, P. D'Angelo, S. De Panfilis, M. Sandström and L. Eriksson, Chem.-Eur. J., 2008, 14, 3056-3066.

54 P. D'Angelo, F. Martelli, R. Spezia, A. Filipponi and M. A. Denecke, Inorg. Chem., 2013, 52, 10318-10324.

55 A. Ikeda, T. Yaita, Y. Okamoto, H. Shiwaku, S. Suzuki, T. Suzuki and Y. Fujii, Anal. Chem., 2007, 79, 8016-8023.

56 L. Rao and G. Tian, Inorg. Chem., 2009, 48, 964-970.

57 P. G. Allen, D. K. Veirs, S. D. Conradson, C. A. Smith and S. F. Marsh, Inorg. Chem., 1996, 35, 2841-2845.

58 The Chemistry of the Actinide and Transactinide Elements, ed. L. R. Morss, N. M. Edelstein and J. Fuger, Springer, Dordrecht, The Netherlands, 4th edn, 2010.

59 M. R. Antonio, R. J. Ellis, S. L. Estes and M. K. Bera, Phys. Chem. Chem. Phys., 2017, 19, 21304-21316.

60 G. T. Morgan and H. D. K. Drew, J. Chem. Soc., Trans., 1920, 117, 1456-1465.

61 J. Xi, J.-H. Lan, G.-W. Lu, Y.-L. Zhao, Z.-F. Chai and W.-Q. Shi, Mol. Simul., 2014, 40, 379-386.

62 S. Andersson, K. Eberhardt, C. Ekberg, J.-O. Liljenzin, M. Nilsson and G. Skarnemark, Radiochim. Acta, 2006, 94, 469-474.

63 A. Fratiello, V. Kubo-Anderson, S. Azimi, E. Marinez, D. Matejka, R. Perrigan and B. Yao, J. Solution Chem., 1992, 21, 651-666.

64 S. Kelly, D. Hesterberg and B. Ravel, in Methods of Soil Analysis. Part 5: Mineralogical Methods, ed. A. L. Ulery and L. R. Drees, Soil Science Society of America, Madison, WI, 2008, pp. 387-464.

65 M. A. Silver and T. E. Albrecht-Schmitt, Coord. Chem. Rev., 2016, 323, 36-51.

66 S. K. Cary, M. A. Silver, G. Liu, J. C. Wang, J. A. Bogart, J. T. Stritzinger, A. A. Arico, K. Hanson, E. J. Schelter and T. E. Albrecht-Schmitt, Inorg. Chem., 2015, 54, 11399-11404.

67 J. A. Drader, M. Luckey and J. C. Braley, Solvent Extr. Ion Exch., 2016, 34, 114-125.

68 A. W. Knight, R. Chiarizia and L. Soderholm, Solvent Extr. Ion Exch., 2017, 35, 266-279.

69 G. K. Liu, V. V. Zhorin, M. R. Antonio, S. T. Li, C. W. Williams and L. Soderholm, J. Chem. Phys., 2000, 112, 1489-1496.

70 I. A. Charushnikova, A. M. Fedoseev and V. P. Perminov, Radiochemistry, 2015, 57, 111-121.

71 J. F. Corbey, B. M. Rapko, Z. Wang, B. K. McNamara, R. G. Surbella, K. L. Pellegrini and J. M. Schwantes, Inorg. Chem., 2018, 57, 2278-2287.

72 C. Den Auwer, M. C. Charbonnel, M. G. B. Drew, M. Grigoriev, M. J. Hudson, P. B. Iveson, C. Madic, M. Nierlich, M. T. Presson, R. Revel, M. L. Russell and P. Thuéry, Inorg. Chem., 2000, 39, 1487-1495.

73 D. Girnt, P. W. Roesky, A. Geist, C. M. Ruff, P. J. Panak and M. A. Denecke, Inorg. Chem., 2010, 49, 9627-9635.

74 A. Bremer, C. M. Ruff, D. Girnt, U. Müllich, J. Rothe, P. W. Roesky, P. J. Panak, A. Karpov, T. J. J. Müller, M. A. Denecke and A. Geist, Inorg. Chem., 2012, 51, 5199-5207. 75 C. Ekberg, E. Löfström-Engdahl, E. Aneheim, M. R. S. Foreman, A. Geist, D. Lundberg, M. Denecke and I. Persson, Dalton Trans., 2015, 44, 18395-18402. 
76 T. S. Grimes, P. R. Zalupski and L. R. Martin, J. Phys. Chem. B, 2014, 118, 12725-12733.

77 A. B. Usov, Radiokhimiya, 1987, 29, 118-121.

78 V. N. Kosyakov, E. A. Yerin and V. M. Vitutnev, J. Radioanal. Chem., 1980, 56, 83-92.

79 R. Chiarizia, P. R. Danesi, G. Scibona and L. Magon, J. Inorg. Nucl. Chem., 1973, 35, 3595-3604.

80 G. F. Best, E. Hesford and H. A. C. McKay, J. Inorg. Nucl. Chem., 1959, 12, 136-140.

81 M. P. Jensen and A. H. Bond, J. Am. Chem. Soc., 2002, 124, 9870-9877.

82 V. I. Vasilyev, E. S. Kalevich, V. M. Radchenko, E. V. Shimbarev, V. P. Egunov, A. N. Izmalkov and V. Y. Vasilyev, J. Radioanal. Nucl. Chem., 1990, 143, 269-274.

83 V. I. Vasilyev, E. S. Kalevich, V. Radchenko, V. P. Egunov, A. N. Izmalkov, E. V. Shimbarev and V. Y. Vasilyev, Radiokhimiya, 1990, 32, 6-8.

84 R. M. Smith and A. E. Martell, Critical Stability Constants, Plenum Press, New York, 1989, vol. 4, p. 443.

85 R. M. Smith and A. E. Martell, Critical Stability Constants, Springer Science, New York, 1976, vol. 4.
86 T. Kimura, Y. Kato, H. Takeishi and G. R. Choppin, J. Alloys Compd., 1998, 271-273, 719-722.

87 Brookhaven National Laboratory, National Nuclear Data Center, http://www.nndc.bnl.gov/chart/.

88 B. Ravel and M. Newville, J. Synchrotron Radiat., 2005, 12, 537-541.

89 F. Neese, Wiley Interdiscip. Rev.: Comput. Mol. Sci., 2018, 8, 49.

90 J. P. Perdew, K. Burke and M. Ernzerhof, Phys. Rev. Lett., 1996, 77, 3865-3868.

91 D. A. Pantazis and F. Neese, J. Chem. Theory Comput., 2009, 5, 2229-2238.

92 D. A. Pantazis and F. Neese, J. Chem. Theory Comput., 2011, 7, 677-684.

93 F. Weigend and R. Ahlrichs, Phys. Chem. Chem. Phys., 2005, 7, 3297.

94 S. Grimme, J. Antony, S. Ehrlich and H. Krieg, J. Chem. Phys., 2010, 132, 154104.

95 S. Grimme, S. Ehrlich and L. Goerigk, J. Comput. Chem., 2011, 32, 1456-1465. 